\title{
PLACE BRANDING BRAZIL: RESEARCH AGENDA AND ADVISORY PANEL FOR THE $21^{\text {ST }}$ CENTURY
}

\author{
Marco Antonio de Moraes Ocke \\ Federal University of Santa Catarina - UFSC \\ Florianópolis, Santa Catarina- Brazil \\ marco.ocke@ufsc.br \\ Allan Augusto Platt \\ Federal University of Santa Catarina - UFSC \\ Florianópolis, Santa Catarina- Brazil \\ allan.platt@ufsc.br
}

Objective: The paper aims to present a research agenda and advisory panel for scholars, branding practitioners and marketers over a place branding perspective in the Brazilian context.

Approach: Bibliographic analysis based on the place image construct built from competitive identity and the achievement of place reputation under a nation branding overview with its economic, political and cultural-critical orientations.

Findings: Guidelines and implications on place brand management and place branding meta trends. The management blueprint consists of a place branding organization to coordinate actions and stakeholders in decision-making stages; an umbrella branding program that benefit different sectors of the economy; place brand measurement to monitor results. The meta trends roadmap is related to a green place brand orientation and positioning as a competitive asset; branding places in a digital transformation context; challenges and opportunities for place branding post Covid-19.

Contribution: This work outlines that strong leadership and efficient planning for place management should prevail over mistaken political measures that weaken place brand equity, otherwise, the country's socioeconomic development, place image and reputation are at risk of being continuously compromised.

Relevance: This research draws attention, stimulates the debate and suggests pathways where place branding principles may provide the lever in need to encourage Brazilian leaderships to cooperate and collaborate more consistently and effectively to properly tackle forward challenges in the $21^{\text {st }}$ century.

Keywords: Place Branding. Research Agenda. Advisory Panel. Brazil.

\section{How to cite the article}

American Psychological Association (APA) 


\section{Introduction}

Place branding popularity is observed in the increase of papers and journals in the last two decades, as well as the boost of book titles and academic events on the subject. The same is noticed in significant investment growth in place branding initiatives regarding competition for resources, investors, skilled workers and visitors among locations of varying scale and complexity around the globe with branding projects performed by consultancy firms and advisory personnel. This phenomenon might be explained by the fact that place branding is not limited to one scientific area. Rather, it is a multidisciplinary field of investigation, involving a range of perspectives, different starting points, terminologies, theoretical structures and empirical approaches. While involving a range of disciplines is clearly advantageous, there is also an evident risk of disagreement in a field that crosses disciplinary boundaries. In this sense, place branding and its expansion into broader and more diversified fields that can benefit from its knowledge is precisely the treatment noticed in cutting-edge studies worldwide.

Despite the increasing presence of place branding in theory and practice, the brand analysis of places is, in fact, anchored in corporate brand strategies which means place and corporate brand management are multidisciplinary in origin, involve various interest groups, are endowed with intangibility and complexity, span multiple identities and require long-term development to achieve satisfactory results. In this context, both in theory and practice, there are varied perspectives on initiatives addressing brand-forming attributes of a place as well as the participation of different players in the construction and management of place brand and a diversity of target markets. As a result, applying the concept of branding to places must be viewed as a distinct form of branding. Its multifaceted essence and implementation challenges due to policies regarding the management of places allow us to suggest the need for a collective understanding and appreciation of the concept.

Place branding literature shows that the concept, as it is understood and currently accepted worldwide, is the result of an evolutionary transition: from place promotion through place planning which ultimate resulted in the place marketing concept as it is best known (Dinnie, 2004; Van Ham, 2008; Kavaratzis \& Ashworth, 2008; Ocke \& Ikeda, 2014). This transition can be grouped under perspectives that did not follow a specific chronology, have relatively undefined distinctions and are integrated in the essence of place branding. Still, each stage has not been replaced by the next, but they coexist, so that, at any time, features of a given phase can be found acting on the same object. By the findings regarding place branding evolution (Kotler \& Gertner, 2002; Anholt, 2008; Gertner, 2011; Lucarelli \& Berg, 2011; 
Boisen, Terlouw, Groote \& Couwenberg, 2018), there are clear advances, especially in terms of the transition from the fragmented concept of place promotion and commercialization of places to the strategic marketing planning process, culminating in the contemporary place branding approach, oriented to improve basic and elaborated urban conditions, attract domestic or foreign investment, qualified workforce, companies, students and visitors.

Place marketing and branding still face the skepticism about the hypothesis that these practices increase the prosperity of a given region and, in the long run, create conditions to improve social well-being. At the heart of the criticism, lies the argument that the manufacture of spectacular urban landscapes and the images that accompany them not only gives rise to social and cultural injustices, but, in fact, serve as a subterfuge to divert the attention of local citizens avoiding the popular contestation of these inequalities (Hall \& Hubbard, 1998; Judd \& Fainstein, 1999; Eisinger, 2000). This controversial bias is enhanced by the lack of evidencebased research that seeks to establish the effectiveness of place branding, demonstrating significant actions and results for socioeconomic development. In general, literature is presented with great amount of qualitative descriptive research using the case method, mainly in European developed regions (Kavaratzis, 2009; Go \& Govers, 2012), while quantitative estimates of expenditures and ROI for place branding efforts are rarely available (Hart \& Stachow, 2010; Herezniak \& Morawska, 2015; Jacobsen, 2012).

This scenario request place branding praxis and research to be able to provide credible responses, identifying and suggesting effective ways of integrating methods to be used as metrics to evaluate the return on investment in such initiatives. However, the inability to justify place branding expenses through its financial return remains a gap that has been partially filled with the evolution of knowledge and better understanding of the concept and this has been the latest focus among scholars and practitioners (Jacobsen, 2012; Herstein, Berger \& Jaffe, 2014; Florek \& Kavaratzis, 2014; Mariutti \& Giraldi, 2019, 2020, 2021). In this attempt, place branding state-of-the art has been developed over studies regarding place brand equity which reinforces the connection with corporate brand strategies, particularly in the notion of the customer-based brand equity - CBBE (Keller, 1993). Although the concept of brand equity is widely accepted, the very notion of brand value applied to places has much yet to evolve since its understanding in the corporate spectrum is uncertain, as there are several forms of presentation due to different measurement purposes and, as a consequence, many approaches have been proposed to estimate brand value (Oliveira, Stefanan \& Lobler, 2018). Among marketing studies, mainly in emergent countries, a single and uniformly accepted theoretical 
basis has not yet emerged and although the corporate world recognizes it as an important marketing activity, professionals and scholars are still challenged to estimate and demonstrate brand value results.

Another remarkable topic in place branding metrics is the compound of worldwide competitive rankings for cities, regions and countries since favorable positioning can secure bigger budgets for current and forthcoming projects. The most credible rankings are those produced by reputable organizations, and which are structured by robust research which is timeconsuming and expensive (Jacobsen, 2012). Understanding rankings methodology is important once each one comes with its own limitations and, for this reason, its relevant to take in account different studies for determining or measuring place branding success. Also, most rankings are not comprehensive and limited to economic indicators whereas intangible features of a place are difficult to evaluate and capture in rankings. In this regard, as stated by Anholt (2020), the role of place image stands out, especially for countries, since the positive overall perception that a place contributes in some substantial way to the world outside its own borders can value its attractiveness and economic development in the long run.

In fact, one of the most discussed subjects in place branding studies is the place image construct built from the place competitive identity and, to some extent, the achievement of place reputation (Anholt, 2010b; Bell, 2016; Mariutti, 2017, Pedeliento, \& Kavaratzis, 2019). Literature outlines that place branding execution relies on a feature mapping, culture and customs diagnoses to reach a deep understanding of how these assets can benefit place image. This way, all competitive advantages of a place must be effectively communicated in order to build and manage a solid image in accordance with its attributes and aligned to the specifics of its audiences. According to Gaio and Gouveia (2007), this perspective suggests that place branding strategies operate along a continuum between the competitive assets on territorial scope and public recognition and interest for these features, in other words, on a continuum between the identity and the image of the place. In these terms, place identity is an emitting concept, which refers to a dynamic phenomenon between the political dimension, the territorial tangibles and the results of socioeconomic and technological interactions of people in space, whereas the image is a receiving concept because it reflects the way it is perceived by the public (Dinnie, 2015). On the other hand, place reputation differs from place image in that it is centered on impressions built around numerous images and actions as an aggregate over time (Passow, Fehlmann, \& Grahlow, 2005). Eventually, place branding as a reputation-building 
tool is essentially a long-term cumulative effort grounded on inwards and outwards markets aligned perceptions of the place.

A fundamental thought on place branding complexity relies on the difficult task of describing the nature of places, once they are social constructs embodied on a physical space where different activities occur. Places are continuously rebuilt entities through administrative, social and political processes that assign meaning and trigger emotions that influence how people perceive, experience and value the environment (Cheng, Kruger, \& Daniels, 2003; Relph, 2004, Campelo, Aitken, Gnoth, \& Thyme, 2009). Aligned with the assumption of place as geographical sense from towns, cities, regions, to entire countries (Hanna \& Rowley, 2008), services marketing literature provides us with important concepts contribution such as the augmented product (Shostack, 1977) and the service-dominant logic (Vargo \& Lusch, 2008; Warnaby, 2009; Warnaby \& Medway 2013). The service economy and intangible attributes have reached space in the composition of the place product, including elements and particularities that could provide a greater offer of opportunities for current and potential markets (Ocke, 2018). This construct constitutes a better visualization and a particular comprehension of place as physical compound imbued with social meaning resulting in a combination of many different aspects that contributes to a place's distinctness.

In terms of size and complexity of places, countries are considered an important area of studies in place branding. From a political and cultural-critical perspective, nation branding is characterized by an inward focus, where it is mostly perceived as a way to reset nations both by means of ideology and praxis. Literature attributed to the political approach sees nation branding as an augmented form of propaganda to build and manage reputation by promoting a country's economy, culture, history and geography. However, most definitions of nation branding are attributed to the economic perspective, of which, in terms of numbers, is by far the most common in scholarly publications (Olins, 2002; Kotler \& Gertner, 2002; Anholt, 2007; Aronczyk, 2009; Govers \& Go, 2009; Fan, 2010; Kaneva, 2011; Dinnie, 2015). The economic approach discusses nation branding as a strategic means to boost a country's competitive advantage in a global scenario with the purpose to promote the nation to its markets, to make it appear more attractive and to support public diplomacy efforts. As a result, nation branding is considered a metaphor for how effectively countries compete with each other for favorable perception in regard to exports, governance, tourism, investment and immigration, culture and heritage, and people (Anholt, 2020). In this sense, the main emphasis relies on the economic imperative competition and measures to ensure a favorable reputation among target audiences. 
Having portraited some important distinctions and advances along the years, this work sets foot in the necessary awareness for place branding in the Brazilian context once the majority of contributions is widely originated from Europe, North America and Asia (Van Ham, 2008; Gertner, 2011; Dinnie, 2015), whereas in Brazil and many other locations in Latin American countries, discussions have a tendency to be focused on destination branding only (Kotler, Gertner, Rein \& Haider, 2006) instead of building a deeper comprehensive approach to incorporate full place branding elements to balance the strategies of each country within the continent (Zenker \& Jacobsen, 2015). In this context and willing to attend the special edition of the Brazilian Journal of Marketing, the main objective of this paper is to present a research agenda and advisory panel for scholars, branding practitioners and marketers in order to draw attention, stimulate the debate and suggest pathways where place branding principles may provide the lever in need to encourage Brazilian leaderships to cooperate and collaborate more consistently and effectively to properly face some of the upcoming challenges in the $21^{\text {st }}$ century (Harari, 2019). In this sense, a conscious and well-orchestrated joint work of scholars and professionals from different sectors to discuss place branding initiatives can bring positive results to collaborate with the Latin American community.

To achieve its goals, the paper presents a bibliographic analysis based on a literature review covering two main place branding pillars: nation branding, with its economic, political and cultural-critical perspective; and the place image construct, built upon the continuum from competitive identity to the achievement of place reputation. Conducted by examining papers published at high impact journals in the place branding field and books written by internationally recognized authors within the last two decades, the bibliographic analysis offered a substantial compound of concepts to lead the paper discussion which outlines the urge of a nation brand management perspective for the Brazilian context by revisiting a glimpse of the country's identity, image and reputation, especially focused on its political and economic perspectives in recent years. It is then presented an agenda-setting and panel structure centered on a nation branding perspective in the Brazilian context enhancing two main corollaries: place brand management and place branding meta trends.

The compound of place brand management consists of effective ways of assembling a formal body to coordinate actions and actors recognizing stakeholders participation in the decision-making stages; the cooperation among governors and leaderships to achieve common goals under an umbrella branding program to benefit different sectors of the economy where they are marketed and branded in a consistent manner within the nation which they form a part; 
the keen to apply integrating methods to measure and evaluate results of place branding efforts. The implications regarding place branding meta trends are helpful for guiding further studies and refer to a green place brand orientation and positioning as a competitive asset; branding places in a digital transformation context where expanded network of information and communication technology enables the connection of data-driven places, people and organizations; place branding post Covid-19 with its challenges and opportunities for rebuilding economies and improve place perceptions. It is hoped that these guidelines illustrate that strong place leadership and efficient planning for place development should prevail over mistaken political measures that weaken place brand equity, otherwise, the country's socioeconomic development, place image and reputation are at risk of being continuously compromised.

\section{Nation branding}

National brands are not much different from the conceptualization of place brands and the vast majority of academic literature on nation branding discusses it as a strategic means to boost a country's competitive advantage. While the majority of nation brands are created based on existing culture and traditions and thus to some extent justified, they tend to be market oriented which means it can be both a positive channel to encourage responsible citizens and a tool for propaganda which warrants concerns, such as the potential impact on different stakeholders. Seen as a set of ideas, emotions, or collections of perceptions, managing a country brand is largely intangible and socially constructed process once a multi-dimensional blend of elements provides the nation with culturally grounded differentiation and relevance. In this scenario, literature on nation branding seems to either praise or argue against the concept, largely depending on the underlying ontological assumptions with regard to social power and national identity.

While academic literature on place branding and national branding does not always strictly distinguish between the two terms, a subtle difference can be found in regard to the inward vs. outward focuses of the two concepts. As Olins and Hildreth (2011) describes, unlike place branding's outward focus, national branding, at least from a political or cultural-critical perspective, is associated with nation-building and characterized by an inward focus, where it is mostly perceived as a way to reconstitute nations both by means of ideology and praxis. However, as Moilanen and Rainisto (2009) enhance, the outwards focus expressed by national brands economic approach merge the two concepts in their almost identical purpose to promote 
a certain geographical location to a target audience, to make a place appear more attractive and to support public diplomacy efforts.

Considering an extensive review on nation branding literature, the subject varies significantly in the ways it is presented and discussed. Referring to 186 examined scholarly publications, Kaneva (2011) concludes that a broad distinction can be made between political and cultural-critical approaches and the technical-economic perspective. Whereas scholars exploring nation branding from a cultural-critical perspective understand it as a way to reconstitute nations both by means of ideology and praxis, literature attributed to the political approach sees nation branding, at worst, as an augmented form of propaganda, or, at best, as an inoffensive way of building and managing reputation by promoting a country's economy, culture, history and geography. Nonetheless, most definitions of nation branding can be attributed to the economic perspective, of which is the most common in scholarly publications as the explicit use of marketing language prevails.

\subsection{The Economic Perspective}

As an emerging area of interest, nation branding is being driven mostly by branding practitioners and marketers. The practice shows that there is a lack of concern about the growing tendency of governments to spend larger amounts of public funds on propaganda - in other words, paid messages telling the world about the assets and achievements of their countries and cities, in the hope that this would improve their image. Brand managers usually rely on advertising, public relations, sales, online marketing and other channels to creatively communicate the idea of a place. Inspired by the place promotion era, these techniques do not work isolated since places are judged by what they do, not what they say about themselves (Gold \& Ward, 1994; Anholt, 2007; Dinnie, 2008; Kavaratzis \& Ashworth, 2008). In this sense, the basic principle of a competitive national identity needs to be consistently and substantially proved by real behavior, over the long term. This suggests that this effect cannot be achieved only by persuasive messaging and there might be no correlation between a country's image and the amount it spends on marketing communications acting alone.

According to Anholt (2010a, 2020), who is widely accredited with having coined the term, the way in which nation branding is being used in academic literature and practice is misleading as it suggests a nation could be branded into existence. The author states that national branding is just a metaphor for how effectively countries compete with each other for favorable perception, be it with regard to exports, governance, tourism, investment and 
immigration, culture and heritage, or people. Like other authors sharing the same perspective on nation branding (Olins, 2002; Kotler \& Gertner, 2002; Bell, 2005; Aronczyk, 2009; Govers $\&$ Go, 2009; Fan, 2010; Dinnie, 2015), the main emphasis relies on competition and the purpose of branding a nation is to ensure a favorable reputation with the target audience, that is, the economic imperative. From this viewpoint, nation branding is seen as a mean to build and maintain a country's strategic advantage with the purpose of economic growth and a tool to boost a country's competitive advantage, seeking to feed the hegemony of the market.

The intention of managing a nation brand to ensure favorable reputation among different markets, not only shines on the country itself but also on its companies, products and services, making them appear preferable in the eyes of the consumers. Shimp, Saeed and Madden (1993) used the expression "country equity" to describe the emotional value that consumers associate with a country. This happens when the name of a country helps them to evaluate the products coming from there and to make their purchasing decisions. Even when a country does not consciously manage its brand, people keep an image of it that results from innumerable characteristics and determines attitudes and behaviors in relation to the place and that can be brought up by the simple mention of its name. This has the ability to influence decisions in relation to purchases, investments, migration and travel (Carroll \& McCombs, 2003; Dinnie, 2008). In this context, nation branding concept has been analyzed as a way to strengthen national production, making a place more competitive in the international market by adding value to the country's brands in global competitiveness and protecting them from negative effects arising from national and international government policies (Kotler \& Gertner, 2011).

As a definition proposed by Aaker (1991), brand value is a group of assets and liabilities linked to a brand, its name and symbol, which are added to or subtracted from the value provided by a product or service. Despite the goal of global brands being selling their products and services and not their place of origin, even if it is associated with leverage actions, the emotional value resulting from the association of consumers of a brand with its country of origin can add or subtract the perceived value of a product (Shimp \& Sharma, 1987). In other words, the stereotypes that consumers have of countries and people can transcend as evaluations of specific brands or products and determine, to some extent, buying intentions and consumer behavior (Gnoth, 2002; Gudjonson, 2005; Roper, 2010). However, it is essential to enhance that the activity of benefiting a place, mainly a country, using the branding tool exclusively to support brands in search of competitiveness, may not be considered place branding. Concerned with a country's whole image on the international stage, covering political, economic and 
cultural dimensions, Fan (2010) outlines that national branding goes beyond the narrower purpose of country-of-origin or place brands to promote specific industries and markets. The author suggests that nation branding is not only about promoting certain industries' interests and this type of value-added strategy is a form of co-branding where the names and attributes of locations can add extra value to products, services and brands sold in foreign markets. On the other hand, the reverse can also occur, that is, a country can be promoted with the help of corporate brands and physical products that can generate positive associations in relation to the place, collaborating with its overall image.

The advances found on place branding literature has described the confusion between traditional promotion of a country's sectors and products, such as trade, investment and tourism, and the attempt to improve the national image. Although expensive but relatively straightforward and demonstrably effective, place promotion is indeed a matter of informing potential customers about what's on offer, and using media and messaging to do so while improving place image as a whole is an approach to policy-making far harder to achieve, taking much longer and not easy to be directly measured. As Anholt (2020) points out, if a country's contribution to the global commons is sufficiently innovative, consistent, relevant and demonstrably effective to the real needs of people and planet, the brand strategy doesn't need expend great amounts on advertising, public relations, branding agencies or media owners, since the organic publicity will leverage place image along with the nation several stakeholders as brand ambassadors.

\subsection{The political perspective}

Similarities with the economic perspective can be found on nation branding contributions from a political perspective as coordinated government efforts to manage a country's image in order to promote tourism, investment and foreign relations (Volcic \& Andrejevic, 2011). Literature attributed to the political approach sees nation branding, at worst, as an augmented form of propaganda, or, at best, as an inoffensive way of building and managing reputation by promoting a country's culture, history and geography, a more progressive form of patriotism than its chauvinistic or antagonistic counterparts (Aronczyk, 2009). Scholars pertaining to this political perspective on nation branding are critical about the emphasis on market positioning and competitiveness, stressing that attempts to brand nations can be risky and even counter-productive in that it might create mistrust and prejudice efforts to win the preference of audiences (MacDonald, 2011). 
Another remark is the management of a national brand described as a powerful political tool, especially for small, peripheral nations eager to strengthen their economic position and to compete against the economic, financial or military clout of empowered nations (Volcic \& Andrejevic, 2011). The authors suggest that in an era of capitalist globalization, branding and commercial competition can become the continuation of warfare by other means. To avoid misjudgment and conflicts related to different nations complexity and power, nation branding political studies have advanced towards the concept of public diplomacy which is closely linked to the concept of nation branding, although its importance on a nation-states, city and regional level is growing (Scott-Smith, 2018). From an international relations perspective, Govers (2020) states public diplomacy is about communicating with foreign target markets to establish a dialogue designed to inform and influence and along with place branding as areas of convergence, reflects the processes by which a nation conducts foreign policy by directly engaging with a foreign public in pursuit of reputation management and influence of external audiences.

\subsection{The cultural-critical perspective}

Studies adopting a cultural-critical approach to the exploration of nation branding tend to focus on its implications for national identities, social power relations and agendasetting (Kaneva, 2011). Cultural-critical researchers explore how marketing and branding influence the social sphere and how those practices alter people's perceptions of self and their national identity, linking the discursive dimension of nation branding to constructivist ideas of nationhood. Butler (1998) and Knight (2011) argue that rather than drawing an adequate image of a places' history, nature and traditions, nation brands are distorted versions to accommodate consumers' tastes. Potential consequences of promoting such a distorted or idealistic image of a nation or place could prove problematic once it generates and perpetuates a lie in which the residents must live; thereby robbing a culture of its authenticity (Fesenmaier \& MacKay, 1996). Following this approach, the very practice of marketing and branding is to be treated with caution, since marketing is not a value-free, neutral means of providing products or services to satisfy physical needs. Rather, through its use of specific symbols, ideological discourses and practices, branding actively shapes social relations, for example by granting material consumption a central role in people's lives (Moufahim, Humphreys, Mitussis \& Fitchett, 2007). 
Understood as a compendium of discourses and practices aimed at reconstituting nationhood through marketing and branding paradigms, nation branding from a cultural-critical perspective reveals a certain way of thinking about the role of a nation and its people, whom it seeks to mobilize in the name of economic development (Kaneva, 2011). By doing so, it follows the logic of neo-liberal governance in that it combines the obligations of citizenship with the responsibilities and risks of the entrepreneurship (Volcic \& Andrejevic, 2011). Increasingly close links between nation branding and public policy, through active encouragement, funding, management and control through government organizations, have led to a growing field of critical examinations of nation branding, understood as a form of governance via market imperatives. This way, Volcic and Andrejevic (2011) declare that politicians become the brand community and governments a country's chief marketers, expected to align foreign and domestic policies with the nation brand.

\section{Identity, image, and reputation}

As one of the most extensive field of research on place branding, place image is widely comprehended as a construct built from the management of place competitive identity assets and, to some extent, the achievement of place reputation. Scholars' main contributions outlines that place branding assertive execution relies on a necessary feature mapping, culture and customs diagnoses and a deep understanding of how these assets can benefit place image. Also, the provision of basic services, infrastructure, superstructure conditions, and the set of positive factors perceived by the main targets must be a priority in the search to position the place competitiveness in the global market and reach a solid reputation in the long run. The cost and effectiveness of place brand management strategies depend on the place image as a function of how different audiences form perceptions about it, so a place must diagnose its competitive identity and design a series of coherent and consistent images to all its audiences. All competitive advantages of a place must be effectively communicated in order to build and manage a solid image in accordance with its attributes and aligned to the specifics of its audiences. However, there are inevitable differences in how these elements are perceived by the various markets. Therefore, place branding actions should consider the tangible and intangible manifestations of its reality, as conveyed through their attributes and attractiveness vectors so that they can be perceived by a wide range of targets. 


\subsection{Place identity}

Along the 1990s there was a common concern with the attributes related to the capacity of industries and the way this strength directly influenced the competitiveness of places. Also, another research bias focuses on more specific responses, including interactions between government policies and local public authorities, in addition to organizational responses between public institutions and local partnerships (Fainstein, 1990). This meant that government actions and relations were endowed with significant importance in the construction of a competitive identity. In this sense, scholars have tried to operationalize the determinants of the places' brand identity (Kresl, 1995; Grabow, Henkel \& Hollbach, 1995). As Hall (1998) pointed out, in the search for different and new ways of ensuring that a place is more competitive, global and national rankings have started to gain more importance which can be observed in the advance of place brand indexes and rankings in the coming years. (Kotler et.al, 2006; Anholt, 2006, 2007; Fetscherin, 2010; Zenker, 2011). The service economy and intangible attributes have reached space in the composition of the brand identity, including elements and particularities that could provide a greater offer of opportunities for current and potential markets.

Place branding, through its functional and symbolic dimension, has the ability to substantiate and value place identity by promoting identification and involvement with audiences and simultaneously distinguishing it from competing locations. In this context, place branding strategies act on a continuum between the attributes of the territory and the public recognition and interest for these characteristics, that is, on a continuum between the identity and the image of the place (Gaio \& Gouveia, 2007). While identity is an emitting concept, which refers to a dynamic phenomenon between the political dimension, the territorial tangibles and the results of socioeconomic and technological interactions of people in space, the image is a receiving concept because it reflects the way it is perceived by the public (Dinnie, 2015).

This continuum relies on a simplification of a large number of beliefs, impressions and information linked to a place, which includes many factors such as its history, geography, art, music and famous citizens. Zenker \& Jacobsen (2015) indicate that geographic aspects such as climate, nature, location are decisive factors in the construction of the attributes that form the image of a nation, state, city or community, but do not act in on their own. The authors add that other promotion channels, such as the economic sectors that partially determine the competitive advantages of the place together with its industry, services, resources and legislation, must be taken into account when linking place identity and place image. In this sense, the economy of 
a place, along with the culture and characteristics of its people, acts as an exposition to the world scenario, determining rhythms of development and prosperity, as well as politics as an integral part of these relations is an important channel of information through diplomacy and influence on every part of the image of the place (Anholt, 2010b).

Places have identities with patrimonial, economic, technological, relational, social and symbolic attributes that form the basis of the image-building processes of territories (Van Ham, 2008). According to Kotler, Haider and Rein (1993), it is the knowledge structure relative to a place, in other words, place identity is the set of elements that gives the place a personality or gives it an image. Ashworth and Kavaratzis (2008), from a procedural perspective, clarify place brand management as an effort to select local identity attributes, translate them and communicate them through a positioning strategy, materialized by symbols, arguments and techniques of communication that distinguish the place from competitors and represent value for all their audiences. The techniques used by places to identify and communicate their attributes and added value constitute an effective tool for place competitiveness (Govers \& Go, 2009). Anholt (2007), however, emphasizes that the attributes of places are difficult to define, including their image and the numerous associations they evoke in opposition to goods and services. In this context, locations need to project a strong and substantial image to attract potential buyers through unique and differentiated positioning (Giraldi \& Ikeda, 2009).

Kavaratzis, Warnaby and Ashworth (2014) highlight three ways to communicate the expressions of a place: primary communication, which includes architecture and the physical aspects of locality; secondary communication, which includes formal information through official channels, as well as publicity and public relations actions; tertiary communication, which refers to word-of-mouth communication leveraged by the media and especially by local residents. However, the authors emphasize that managing the image of a place requires greater analytical depth, thus a study of the negative and positive effects that its dissemination can bring to the sites or communities involved and long-term planning that minimizes negative effects and even ensure the maintenance of attractions are main assets in place branding actions.

\subsection{Place image}

Kavaratzis \& Ashworth (2005) suggest that places may be branding entities if their characteristics can differentiate themselves from others. In this context, a name is a brand and, similar to other types of offerings, people can share a consistent set of characteristics, images or emotions when they recall or experience a particular place (Govers \& Go, 2009). The process 
of place image building is based on a set of signs and experiences that individually may not be decisive in the receiver's opinion, but as a whole become fundamental to the construction of a value judgment. Consequently, the image of a place is a basic determinant of how citizens and businesses react to it, so a place must try to manage its image assertively. Dinnie (2015) mentions that even when a place does not consciously manage its brand, people keep an image that results from innumerable characteristics and determines attitudes and behaviors in relation to the place and that can be brought up by the mere mention of its name, influencing decisions regarding purchases, investments, relocation and travel.

Haider, Kotler and Rein (1994) state clearly and objectively the possibility of a place to promote its qualities and manage its image. According to the authors, competition for investments makes it imperative that places take care of their image to become a competitive option. Pennington (2004) stresses that place brand management enhances a synergistic link with economic development, contributing both to attract and retain people and companies and to favor co-branding by extending place image and brand attributes to local products and clusters promoting new and multiple centralities in the territory. Empirical research (Rainisto, 2003; Dinnie, 2007; Anholt, 2008) shows that the images that localities project are important extrinsic indicators in evaluating their products and investment opportunities, leaving no doubt that places brands must be positioned consciously.

As Relph (1976) proposed, place images are not formed simply in terms of patterns of physical and observable features, nor just as products of attitudes, but as an indissociable combination of these characteristics. In addition, place images are highly diverse and multifaceted, partial and often either exaggerated or understated (Shields, 1991). While Haider et al. (1994) describe place image as sum of beliefs, ideals, and impressions people have toward a certain place, Zenker (2011) defines the image of a place as a network of associations in the minds of consumers based on the visual, verbal and behavioral expressions of a place, which are represented through the goals, communication, values and the general culture of the place compound. Place images are further shaped by culture, history and even famous citizens (Florek \& Insch, 2008; Hart \& Stachow, 2010; Murphy, 2010; Dinnie, 2015). In this context, places are surrounded by entire symbolic complexes of images originating from diverse sources and often subject to competing discourses (Papen, 2005; McGibbon, 2006).

Several studies emphasize place image as a controversial side of place branding once people's perceptions of places tend to be vague (O'Shaughnessy \& O'Shaugnessy, 2000), and may not exactly reflect local realities (Anholt, 2007; Walsh \& Wiedmann, 2008). Perceptions 
derived from the process of generalizing to an entire class of objects from a limited number of observations are not easily altered as once established, the core images on which those stereotypes draw tend to be persistent and stable (Coyle \& Fairweather, 2005). In this regard, despite associations and experiences with specific places are likely to differ due to distinctive needs and purposes (Hankinson, 2004; Warnaby, 2009; Hart \& Stachow, 2010), when shared and widely accepted among audiences, their images may become stereotypical for those places (Boisen, Terlouw, \& Bouke, 2011). Also, media representations play a crucial role in the place image context as a major part by which information is disseminated and influencing consumers' images of places and, most of the time, are influenced by the ways in which they are represented by the media (Carroll \& McCombs, 2003; Murphy, 2010; Boisen et al., 2011).

Another aspect of place image controversial nature is that it can develop a meaning beyond or even independent from what first intended by their initiators (Govers \& Go, 2016). This represents that consumer's knowledge, experience, expectations, beliefs, values and motives may result from an interpretation quite different from the one intended by the producer of the message (Kavaratzis, Warnaby \& Ashworth, 2014). These arguments find some meaningful support on Shields (1991) thoughts regarding place images as the various discrete meanings associated with real places regardless of their character in reality. Also, from the viewpoint of place images as public domain, they can be manipulated and exploited by any party with an interest in order to reach certain purposes (Botschen, Promberger, \& Bernhart, 2017) and, besides, brand images are unstable, dynamic and influenced by factors impossible to be fully controlled (Papadopoulos \& Heslop, 2002; Murphy, 2010; Kotler \& Gertner, 2011).

\subsection{Place reputation}

Just as place branding and place reputation are not easily decoupled, place image itself cannot be considered alone a cornerstone to reputation building. In this sense, place promotion implemented in isolation and not adhering to a wider place reputation and management strategic framework are not likely to achieve long term effects for the place and may only bring temporary results (Bell, 2016). As Mariutti (2017) declares, a place must first be improved by development and management before reaching positive reputation, in other words, place management and place reputation must be aligned to develop and improve places for sustainable prosperity. Understood as the aggregate of place images over time (Passow, Fehlmann, \& Grahlow, 2005), place reputation differs from place image in that it is centered on long-term impressions built around numerous images and actions. While place reputation 
operates as a deeper understanding construct of place brand, the image becomes a raw element of a place reputation and is founded on spontaneous understandings (Mariutti \& Giraldi, 2020).

In an organizational context, according to Rindova, Williamson, Petkova and Sever (2005), reputation is generally attributed two dimensions: first, how stakeholders perceive the quality of specific attributes in the context of the firm, and second, the degree to which an organization is recognized collectively. Also, from a business perspective, reputation has been defined as the combination of a firm's public prominence - the degree to which a company is recognized on a large-scale and salient in the minds of stakeholders, its public esteem - the degree to which the public likes, trusts, admires, and respects an organization, and the qualities or attributes associated with it (Rindova et al., 2005, Carroll, 2011). Carroll and McCombs (2003) offer some guiding principles that help understand the influence of news coverage on corporate reputation by stating that the greater the amount of coverage, the greater public awareness; attributes emphasized in media coverage become attributes the public uses to define a firm; and the valence of news coverage, positive or negative, is reflected in corresponding public perceptions about those attributes. Although those principles were developed with business organizations in mind, they can be considered equally valid for understanding the significance of media reputation for place or national brands (Murphy, 2010; Boisen et al., 2011).

Just like the image and reputation of organizations, the meaning of place brands can change and evolve over time, not least due to changes in cultural context and language or societal expectations. As a result, place branding as a reputation-building tool is essentially a long-term cumulative effort, with no guarantee for success (Anholt, 2010b; Roper, 2010). Importantly, however, both a place brand's image and whether the place stands for, the grassroot of norms and values that the audience admires.

\section{Discussion}

The economy of a place, along with the culture and characteristics of its people, acts as an exposition to the world scenario (Kavaratzis, Warnaby \& Ashworth, 2014), determining rhythms of development and prosperity, as well as politics as an integral part of these relations is an important channel of information through diplomacy and influence on every part of the image of the place (Anholt, 2010b). In terms of discrediting the reputation-building efforts of place branding initiatives, mistaken political measures can weaken place brand equity when they fail to align with a place's distinctive characteristics that are attractive to potential markets. 
In other words, while place branding requires consistency to build trust in the long term, ideologies and political interests tend to cast away from stability by creating confusion and unpredictable behavior (Aronczyk, 2009; Volcic \& Andrejevic, 2011). In this context, the case of Brazil illustrates that strong place leadership and efficient planning for place development should prevail over political interest, otherwise, the country's socioeconomic development, place image and reputation are at risk of being compromised by multiple political players, periodic elections, corruption, ideologies and populism.

\subsection{A glimpse of Brazil}

In recent years, a repositioning country brand strategy leveraged Brazil awareness as a promising hub for investment for a great variety of sectors. The overall objective was to add new attributes to the country's image, such as a strong economy of a young and modern renewed country, innovative and sustainable, as well as strengthening the positive characteristics for which the country was already known as its friendly and hospitable people alongside its privileged vast natural beauty. By performing country brand initiatives and hosting mega sporting events as international promotional tools - 2014 FIFA World Cup and the 2016 Olympic Games in Rio de Janeiro - Brazil sought to consolidate itself as a nation featuring high organizational capacity, global economic strength and keen on international cooperation of a thriving democracy and a well-developing economy (Ocke, 2013). However, Brazil did not show its best, but its poor public management and wide-spread corruption which draw the country to a political and economic crisis of a scale never seen before. As a result, the former president Dilma Rousseff faced impeachment proceedings on charges of having illegally financed budget deficits and was removed from the presidency creating a mood of palpable and widespread uncertainty. In the end, the intended positive place image efforts were instead dominated by evident problems and unhappiness within inward markets and became a drawback for international investors which affected the country's reputation negatively.

Later in 2021, a series of damning revelations in congressional hearings examining the government's catastrophic response to the Covid-19 crisis has shown that the right-wing president Jair Bolsonaro has dismissed the threat of the virus, promoted inefficient treatments, opposed lockdowns, criticized social distancing, attended crowded gatherings where he often did not wear a mask and, only more than one year after the outbreak, embraced vaccines as a possible solution despite his anti-vaccine positioning. Besides, the president's constant rhetoric attacks to democracy and poor environmental management efforts, evoked impeachment 
procedures back on the horizon. These denial demonstrations, widely covered by international media (The Economist, 2021; The Guardian, 2021; The New York Times, 2021) characterize the Brazilian government as one of the worst global leaderships dealing with Covid-19 and environmental crisis. This cumulative uncertainty, instability and turbulence which harms the image of Brazil in domestic and foreign markets have turned the country into an international pariah backfiring its overall perception within the global spectrum, reducing brand value, its attractiveness and economic development in the long run.

\subsection{Agenda-Setting and Advisory Panel}

Based on the place image construct built from the place competitive identity and, to some extent, the achievement of place reputation (Anholt, 2010b; Bell, 2016; Mariutti, 2017, Pedeliento \& Kavaratzis, 2019), this section suggest a range of topics to constitute a research agenda and advisory panel for scholars, branding practitioners and marketers in order to draw attention, stimulate the debate and suggest pathways where place branding principles may provide the lever in need to encourage Brazilian leaderships to cooperate and collaborate more consistently and effectively to properly tackle some of the forward challenges in the $21^{\text {st }}$ century (Harari, 2019). This compound of issues takes into account a nation branding perspective in the Brazilian context enhancing two main corollaries: place brand management and place branding meta trends. The place brand management blueprint and its implications consist of (1) place branding organization - effective ways of assembling a formal body to coordinate actions and actors recognizing stakeholders participation in the decision-making stages; (2) umbrella branding program - the cooperation among governors and leaderships to achieve common goals to benefit different sectors of the economy where they are marketed and branded in a consistent manner within the nation which they form a part; (3) place brand measurement - the keen to apply integrating methods to monitor and evaluate results of place branding efforts. The place brand meta trends are insightful for mapping further studies and consist of (4) green place brand orientation - a sustainability positioning as a competitive asset; (5) branding places in a digital transformation context - connection of data-driven places, people and organizations through an expanded network of information and communication technology; (6) place branding post Covid-19 - challenges and opportunities for rebuilding economies and improve place perceptions in a post pandemic scenario. 


\subsubsection{Place branding organization}

A major challenge to develop models and actions for place brand management is the coordination of a great number of players that might impact the performance and image of a place. The lack of coordination and strategies fragmentation may lead to inconsistency in the policies resulting drawback to the effectiveness of place branding in the long run (Rainisto, 2003). Thus, one central team should act as the focal point to keep a tab on the process of brand management, disperse information, monitor success rate, and provide the necessary tools for a successful place branding program. In a country level, having the federal government leading the board is important as it is an overarching entity under which various sectors will benefit from place branding initiatives, however, brand management should be separate from politics (Aronczyk, 2013) and have active participation of productive regions, states, municipalities as well as cultivating public-private partnerships as both partners bring a wealth of information which helps to come up with creative ideas and strategies for place branding implementation.

The efficient PBO should list key components for each activity, including ways of operating and implementing action plans, a matrix of operational costs, execution schedules and the allocation of responsibilities to all participants to avoid conflicting actions (Kavaratzis \& Ashworth, 2008; Ocke \& Ikeda, 2014). Also, driven by their own interests, each of those players can support or detract from the ambitions of establishing and maintaining a certain place brand (Insch, 2011; Botschen et al., 2017). To avoid that, examining the possibilities of cooperation more consistently and effectively among players to reach common objectives is essential to set a standard style and tone of brand messaging especially in such a complex and wide territory as Brazil. This alignment may be the key to establish a body for coordinating actions and integrating methods to help prepare places to deal with an uncertain future, caused by changes in variables in the internal and external environments.

\subsubsection{Umbrella Branding Program}

Place brand management is not controlled by a single entity but by a group of stakeholders seeking a blueprint to take decisions around an identity with distinguishing features so that a place can stand out from others and clearly communicate its benefits and strengths to potential markets, investors, visitors and residents. Since places are composed of these various stakeholders with different priorities and target-markets with specific characteristics, the compound of an umbrella brand (Aaker, 1991; Keller, 1993; Kotler \& 
Gertner, 2011) may be essential in reaching common ground and focusing on the strengths of the country. Branding images of common interest across distinct functional areas through a brand architecture must focus on a unifying strategy that avoid a shared vision of place. It is, in fact, a range of opportunities for governors, policy-making, economic developers, community builders, export chambers, talent attraction agencies, destination marketing organizations, consultants and other place brand managers.

However, the search for a unifying message that brings together different target markets simultaneously lead to the risk of the communication become scattered and abstract, resembling a tasteless non-brand similar to other competing locations, not appealing to any audience or oriented to a particular profile with other targets left behind. To avoid this misleading result, it is essential to enhance greater stakeholders' co-creation (Rainisto, 2003; Zenker, 2011; Govers, 2020) such as community forces, including civil society, entrepreneurs, researchers and specialists in the decision-making process. In these terms, a coherent umbrella branding strategy strengthens the sense of place by performing a consistent narrative across entities as all stakeholders have their own identity and creates alignment between the language and messages channeled for and by different audiences. Efforts and investment must be shared on fragmented branding actions to meet different target markets by working on subdivisions supported by one nation brand identity (Fan, 2010; Kaneva, 2011; Dinnie, 2015). Not only do promotional promises need to be fulfilled in order to achieve credibility and demonstrate integrity, but places should be marketed and branded in a way consistent with the larger place, such as the country of which they form a part.

\subsubsection{Place brand measurement}

Brand management viewed as a way of place governance must consider long-term planning, feasibility studies and analysis of environmental and socio-economic impacts for the execution of efficient and lasting action programs. The effects of a place branding program may take years to get results and, in this context, initiatives must include evaluating metrics based on the objectives proposed by these programs as a set of clear KPI - key performance indicators - to be articulated and agreed on before engaging a place branding initiative (Kavaratzis, 2009; Go \& Govers, 2012). In comparison to other competing cities, regions or countries, success in place branding is always relative, so benchmarking performance can help determine impact. In this regard, the compound of worldwide competitive rankings may provide useful insights since favorable positioning can secure bigger budgets for current and forthcoming projects. Here we 
begin to understand and calculate the return on investment for the talent dimension of place branding, asking ourselves what it costs to attract these markets and for how long do they need to stay and spend to make that investment worthy.

Understanding rankings methodology is important once each one comes with different studies for determining or measuring place branding success and hardly present a tangible brand value construct. Most place brand metrics are not comprehensive and limited to economic indicators whereas intangible features of a place are difficult to measure and to capture in rankings. Economic indicators and quantitative data are relevant, but need to come along with qualitative indicators of place brand equity (Mariutti \& Giraldi, 2021), however, each method has its limitations and thus no approach to success measurement is perfect. Metrics focused on economic, quantitative factors are tricky in that it's difficult to determine causality, once some place image improvements might be due to other factors, not the place branding effort acting alone. Also, quantifying desired outcomes such as happiness, positive experiences, awareness or perception is extremely difficult, expensive and time-consuming, since these metrics involve surveying a wide range of internal and external audiences continuously over time (Anholt, 2020). Eventually, the role of the positive overall perception of the place image can value its attractiveness and economic development in the long run.

\subsubsection{Green Place Brand}

Although the selective positioning and promotion of places based on their natural attractions and environmental credentials are nothing new, with increasing recognition and awareness of environmental issues, emphasis on aspects of environmental sustainability in both corporate branding and place branding have become more frequent. As Morgan, Pritchard and Pride (2011) emphasize, the global context of environmental expectations and growing concerns about environmental degradation, especially climate change, has become indispensable to survive in the global market and is driving places to create a profile that makes them stand out from the crowd, such as by demonstrating environmental leadership. Anholt (2010b) stresses similarly that people, companies and governments feel unable to admire or respect countries that pollute the planet, practice and permit corruption, trample human rights or break environmental laws. In this sense, green place branding transcends into politics and public diplomacy, with countries attempting to win the hearts and minds of the international community (Morgan et al., 2011). 
A green place brand stands where environmental values constitute the brand essence (Insch, 2011) and short-term planning to boost economic activity does not hamper social and environmental sustainability at the expense of fast economic recovery (Kavaratzis \& Florek, 2021). However, if vague or loosely defined, branding a place as green can be prone to accusations of greenwash (Delmas \& Burbano, 2011; Insch, 2011), namely environmental claims made to suggest environmental responsibility which are not backed up with evidence. As Roper (2012) has demonstrated, issues arise where brand promises of environmental integrity clash with political agendas that prioritize economic growth and development. Hence, without integrity, green place branding is a high-risk strategy (Roper, 2010) and, ultimately, a green brand positioning will be successful in the long-term only if the proclaimed attributes and benefits are perceived as environmentally sound (Hartmann, Apoalaza \& Sainz, 2005; First \& Khetriwal, 2008).

Dinnie (2015) observes that destination marketing organizations, in particular, tend to draw heavily on natural attractions, thereby running the risk of overstretching their environmental credentials. This fact has been particularly common in Latin American countries with tendency to brand themselves as destinations only instead of building a deeper comprehensive approach and incorporate full place branding elements to balance strategies (Kotler et. al, 2006). Place brand managers should focus on the natural strengths of the place and its human resources instead of trying to include every element of the place. In this sense, sustainability as place brand positioning could be a global market opportunity for Brazil since its natural environment and a potential clean energy matrix deployment are strong assets of its competitive identity. Denying the climate emergency from a nation and place brand perspective hurts the country, region, or city and its people, while tackling it will conversely help.

\subsubsection{Branding places and digital transformation}

As stated by Kotler, Kartajaya and Setiawan (2021), the application of humanmimicking technologies to create, communicate, deliver and enhance value across the customer journey through a set of technologies - artificial intelligence, natural language processing, robotics, sensor tech, augmented reality, virtual reality, internet of things and blockchain - will emulate the capabilities of the expanding networks of information and communication enabling the connection of places, people and organizations shaping the society 5.0. In this data-driven reality, despite the uneven digitally led urban innovations especially in developing countries such as Brazil and its neighbors in Latin America, the emergence of smart cities is a logical and 
natural development of traditional clusters and their expansion to global connected mega cities (Grebosz-Krawczyk, 2021). Towards a smart place brand orientation, actions should rely on building and developing a competitive local identity founded on strong distinguished features through the implementation of long-term initiatives focused on citizens' inventiveness, collective intelligence and knowledge-based urban development, creating an exclusive and technology-led business innovation ecosystem for highly skilled residents (Kolotouchkina \& Seisdedos, 2018).

As a side effect, technology is moving so fast that democracy is not being able to keep pace, opening the door to a world of widely misunderstood tools and information bases with the ability to both help and hurt social development (Harari, 2019). In this scenario, digitalization has driven this development as increasing sources of information become available and unregulated social media continues to prompt widespread mistruths and misinformation. Countries, regions, and cities must be quick to implement tools, regulation, and honest communication to mitigate the impacts of misinformation. In this context, enhancing digital diplomacy (Collins \& Bekenova, 2019; Collings, DeWitt \& LeFebvre, 2019; Mazumdar, 2021), supporting digital storytelling on place impressions and experiences in meaningful ways (Hudak, 2019), engaging with media outlets boosting integrated messages and enacting brand protection efforts will aid in defending a nation and place brands against deceit and protect not only their reputation, but the local and international community from the end of truth as we know it (Bloom Consulting, 2021).

\subsubsection{Place branding post Covid-19}

Governments around the world face the daunting task of rebuilding their economies as countries try to emerge with an intact reputation from the Covid-19 pandemic. This scenario draws fierce competition among locations to convince investors, talent and visitors to trust their public management and consider them worthy of their time and money. As an immediate impact, creative messaging is the key to communicate health and safety aspects in a way which affects people willingness to visit, live, work or study amongst other priorities of brand audiences. Public policy and its efforts to aid local and global citizens in the search for affordable, quality healthcare is beyond a unique value offer and moreover a basic need of places hoping to attract brand audiences with a certain level of mobility and purchasing power. As shown by a panel of specialists (The Place Brand Observer, 2021) local tourism will increase, owing to the concerted effort by governments to kickstart economic recovery. 
However, environmentally and socially sustainable tourism might not be a priority in many regions in the coming years, as getting local businesses up and running will be the more immediate concern. They also enhance that remote work is becoming increasingly attractive and places worldwide are taking this opportunity to develop talent and tourism programs geared towards attraction, growth, and retention of local and international talent pools. Individuals who are given the opportunity to relocate whether through financial means, freedom of travel, or remote work flexibility, will seek a new quality of life previously inaccessible to most of the global community. This shift in offer as well as demand in terms of working lifestyle accelerated by the pandemic brings massive opportunities for some locations, especially those perceived as safe and which demonstrated good crisis management and remained accessible during the pandemic.

Kavaratzis and Florek (2021) consider that the events that took place along Covid-19 pandemic emphasized the need to understand the role of place branding in times of crisis, one of the most relevant topics of discussion in further agenda, both in terms of ensuring health protocols and in regard to reviving the economy. Through a research of country perception analysis (Bloom Consulting, 2021), quick and effective government responses to crises have a significant impact on place brands. The flipside, places, including Brazil, that react slowly and ineffectively are equally as negatively impacted. This is the red line countries, regions and cities need to be aware of falling below of exceeding and seeing an impact in perceptions, thus it is an opportunity for governments to win significant occurrences whether local, regional or global. In these terms, places must pay special attention to policies being developed round the globe and destinations implementing programs to attract talent, visitors and investors by improved perceptions. In the sense of a country complexity in such difficult times, as stated by Anholt (2020), the role of a nation within the global context stands out since the positive overall perception of its contribution in some substantial way to the world outside its own frontiers. That it is a principled and collaborative actor in the international community, which improves lives of many more people than its own citizens and benefits more of the planet than its own share of territory. Eventually, countries that rebound successfully from Covid-19 crisis will be those that get their nation branding program well performed and effective in terms of health protocols, vaccine diplomacy, politics, economics, tourism, immigration and talent attraction enhancing place brand value, its attractiveness and economic development in the long run. 


\section{Conclusions}

It is intrinsic to the concept of place branding the need to shape a strategic vision to meet challenges through market-driven planning. Places need to diversify their competitive assets and develop mechanisms to adapt flexibility to conditions, fostering and cultivating entrepreneurial characteristics towards contemporary challenges. This thought might suggest that national brand management should contribute to prosperity, increasing the living standards of the country in all aspects, which incurs economic, political and cultural factors once benefits of place branding initiatives are varied and include the ability to receive more direct investments due to the country's solid overall image including elements about safety, environment, political and economic stability, in addition to the opportunity to use a "made in" label on brands, products and services to leverage sales numbers.

This paper limitations reside on the complex nature of place branding itself and the varied perspectives addressing brand-forming attributes of a place, its diversity of target markets, stakeholders and the comprehension that its roots must be understood as a distinct form of branding. Place branding is multidisciplinary in essence, involves different interest groups, is embodied with intangibility and complexity, spans multiple identities and requires long-run development to reach satisfactory results. Also, this work does not provide the community with answers to avoid pitfalls such as the misusage of place branding as shallow promotional tool and does not enhance the need to attend urgent demands of more integrative and effective development of the basic place product benefiting inward markets, especially in developing countries such as Brazil and its neighbors in Latin America. These drawbacks may reinforce the utopic perspective of a place branding mechanism as a special link to integrate stakeholders with particular interests and the skepticism about the hypothesis that place branding increases prosperity of a given region by creating improved conditions of social wellbeing.

Finally, this work intention is to call a necessary awareness for place branding research and praxis in the Brazilian context since the majority of contributions is widely originated from Europe, North America and Asia. The main purpose is to present pathways where place branding principles may provide the lever in need to encourage Brazilian leaderships to cooperate and collaborate more consistently and effectively to properly face forward challenges since long term planning for place development should prevail over political interest, otherwise, the country's socioeconomic development, place image and reputation are at risk of being continuously discredited. It is hoped that the blueprint presented in the agenda-setting provides 
useful insights for both scholars and practitioners and, in this sense, further researches are recommended to use this roadmap and explore the subject in the Brazilian spectrum not only in terms of a nation, but also examining the phenomenon along the country's productive regions, economic clusters, states, cities and districts, each one with its own complexity and reality.

\section{References}

Aaker, D. (1991). Managing brand equity. New York: Free Press.

Anholt, S. (2006). Anholt City Brand Index - How the World Views Its Cities (2nd ed). Global Market Insight, Bellevue, WA.

Anholt, S. (2007). Competitive identity: The new brand management for nations, cities and regions. Houndsmills, United Kingdom: Palgrave Macmillan.

Anholt, S. (2008). Editorial: Place branding: Is it marketing, or isn't it? Place Branding and Public Diplomacy, 4(1), 1-6.

Anholt, S. (2010a). Why 'nation branding' doesn’t exist, The Economic Times.

Anholt, S. (2010b). Places: Identity, image and reputation. Houndsmills, United Kingdom: Palgrave Macmillan.

Anholt, S. (2020). The Good Country Equation: How we can repair the world in one generation. Oakland, CA: Berrett-Koehler Publishers.

Aronczyk, M. (2009). Branding the nation: Mediating space, value, and identity in the context of global culture. (PhD thesis), New York University, New York, NY.

Aronczyk, M. (2013). Branding the Nation: The Global Business of National Identity. England: Oxford University Press.

Ashworth G. J., \& Kavaratzis, M. (2008). Place marketing: how did we get here and where are we going? Journal of Place Management and Development, 1(2), 150-165.

Bell, C. (2005). Branding New Zealand: The national green-wash. British Review of New Zealand Studies, 15, 13-27.

Bell, F. (2016) Looking beyond place branding: the emergence of place reputation. Journal of Place Management and Development, 9 (3): 247-254.

Bloom Consulting. (2021). Meta trends and implications for nations and place brands. Available at: https://www.bloom-consulting.com/journal/ Access in October 4 ${ }^{\text {th }}, 2021$.

Boisen, M., Terlouw, K., \& Bouke, V.G. (2011). The selective nature of place branding and the layering of spatial identities. Journal of Place Management and Development, 4(2), 135 147. 
Boisen, M., Terlouw, K., \& Groote, P., \& Couwenberg, O. (2018) Reframing place promotion, place marketing, and place branding-moving beyond conceptual confusion. Cities, 80: 4-11.

Botschen, G., Promberger, K., \& Bernhart, J. (2017). Brand-driven identity development of places. Journal of Place Management and Development, 10(2), 152-172.

Butler, R. (1998). Tartam mythology: The traditional tourist image of Scotland. In G. Ringer (Ed.), Destinations: Cultural landscape of tourism (121-139). London, UK: Routledge.

Campelo, A., Aitken, R., Gnoth, J., \& Thyme, M. (2009). Place branding: Representing sense of place. Paper presented at the Australia and New Zealand Marketing Academy (ANZAM) Conference, Monash University, Melbourne, Australia

Carroll, C.E., \& McCombs, M. (2003). Agenda-setting effects of business news on the public's images and opinions about major corporations. Corporate Reputation Review, 6(1), $36-46$.

Carroll, C.E. (2011). Corporate reputation and the news media in the United States. In C.E. Carroll (Ed.), Corporate reputation and the news media: Agenda-setting within business news coverage in developed, emerging, and frontier markets (221-240). New York, NY: Routledge.

Collins, N., Bekenova, K. (2019) Digital diplomacy: success at your fingertips. Place Branding and Public Diplomacy 15, 1-11.

Collins, S.D., DeWitt, J.R. \& LeFebvre, R.K. (2019). Hashtag diplomacy: twitter as a tool for engaging in public diplomacy and promoting US foreign policy. Place Branding and Public Diplomacy 15,78-96.

Coyle, F., \& Fairweather, J. (2005). Challenging a place myth: New Zealand's clean green image meets the biotechnology revolution. Area, 37(2), 148-158.

Cheng, A., Kruger, L., \& Daniels, S. (2003). 'Place' as an integrating concept in natural resource politics: Propositions for a social science research agenda. Society \& Natural Resources: An International Journal, 16(2), 87-104.

Delmas, M.A., \& Burbano, V.C. (2011). The drivers of greenwashing. California Management Review, 54(1), 64-87.

Dinnie, K. (2004). Place branding: overview of an emerging literature. Place Branding and Public Diplomacy, 1(1), 106-110.

Dinnie, K. (2008). Nation branding: Concepts, issues, practice. Oxford, United Kingdom: Butterworth-Heinemann.

Dinnie, K. (2015). Nation Branding: Concepts, Issues, Practice. ( $2^{\text {nd }}$ ed). Routledge.

Eisinger, P. (2000). The politics of bread and circuses. Building the city for the visitor class. Urban Affairs Review, 35(3), 316-333. 
Fainstein S. (1990). The changing world economy and urban restructuring. (Judd, D., \& Parkinson, M. Eds) Leadership and Urban Regeneration, 31-50. Newbury Park: Sage

Fan, Y. (2010). Branding the nation: Towards a better understanding. Place Branding and Public Diplomacy, 6(2), 97-108.

Fesenmaier, D., \& MacKay, K. (1996). Deconstructing destination image construction. Tourism Review, 51(2), 101-108.

Fetscherin, M. (2010) The determinants and measurement of a country brand: the country brand strength index. International Marketing Review, 27 (4): 466-479

First, I., \& Khetriwal, D.S. (2008). Exploring the relationship between environmental orientation and brand value: Is there fire or only smoke? Business Strategy and the Environment, 19, 90-103.

Florek, M., \& Insch, A. (2008). The trademark protection of country brands: Insights from New Zealand. Journal of Place Management and Development, 1(3), 292-306.

Florek, M., \& Kavaratzis, M. (2014). From brand equity to place brand equity and from there to the placebrand. Place Branding and Public Diplomacy, 10 (2): 103-107.

Gaio. S., \& Gouveia, L. (2007). O Branding Territorial: Uma Abordagem Mercadológica à Cidade. Revista A Obra Nasce, Edições UFP, 27-36.

Gertner, D. (2011). Unfolding and configuring two decades of research and publications on place marketing and place branding. Place Branding and Public Diplomacy, 7(2): 91-106.

Giraldi, J. M. E., \& Ikeda, A.A. (2009). Uma Aplicação da Abordagem de Personificação no Estudo de Imagem de País. BBR. Brazilian Business Review. 6(1), 137-153.

Gnoth, J. (2002). Leveraging export brands through a tourism destination brand. Journal of Brand Management, 9(4/5), 262-280.

Go, F., \& Govers, R. (2012). International Place Branding Yearbook 2012: Managing Smart Growth and Sustainability. London: Palgrave Macmillan.

Gold, J.R., \& Ward, B. (Eds.). (1994). Place promotion: The use of publicity and marketing to sell towns and regions. Chichester, UK: John Wiley \& Sons Ltd.

Govers, R., \& Go, F. (2009). Place Branding: Virtual and Physical Identities, Glocal, Imagined and Experienced. Palgrave-Macmillan, Basingstoke.

Govers, R., \& Go, F. (2016). Place branding: Glocal, virtual and physical identities, constructed, imagined, and experienced. Springer.

Govers, R., \& Go, F. (2009). Place branding: Glocal, virtual and physical identities, constructed, imagined and experienced. Basingstoke, United Kingdom Palgrave Macmillan. 
Govers, R. (2020). Imaginative communities and place branding. Place Branding and Public Diplomacy 16, 1-5.

Grabow, B., Henckel, D., Hollbach, B. (1995). Weiche Standortfaktoren (Soft Location Factors), Kohlhammer/Deutscher Gemeindeverlag, Berlim.

Grebosz-Krawczyk, M. (2021) Place branding (r)evolution: the management of the smart city's brand. Place Branding and Public Diplomacy 17, 93-104.

Gudjonson, H. (2005). Nation Branding. Journal of Place Branding, Vol 1, pp.283-298.

Haider, D., Kotler, P., \& Rein, I. (1994). There's no place like our place! Public Management, 76(2), 15-18.

Hall, T. (1998). Urban Geography, London: Routledge.

Hall, T., \& Hubbard, P. (1998). The entrepreneurial place and the new urban politics. In T. Hall \& P. Hubbard (Eds), The entrepreneurial place: geographies of politics, regime and representation (1-23). Chichester: Wiley.

Hankinson, G. (2004). The brand images of tourism destinations: A study of the saliency of organic images. Product \& Brand Management, 13(1), 6-14.

Hanna, S., \& Rowley, J. (2008). An analysis of terminology in place branding. Place Branding and Public Diplomacy, 4(1), 61-75.

Harari, Y.N. (2019). 21 lessons for the $21^{\text {st }}$ century. United Kingdom: Vintage Publishing.

Hart, C., \& Stachow, G. (2010). Exploring place image: Formation and measurement. Journal of Place Branding and Public Diplomacy, 6(2), 145-155.

Hartmann, P., Apoalaza Ibáñez, V., \& Forcada Sainz, F.J. (2005). Green branding effects on attitude: Functional versus emotional positioning strategies. Marketing Intelligence \& Planning, 23(1), 9-29.

Herezniak, M., \& Morawska, A. J. (2015) City brand strategy evaluation: in search of effectiveness indicators. Journal of Place Management and Development, 8(3), 187-205.

Herstein, R., Berger, R., \& Jaffe, E.D. (2014) How companies from developing and emerging countries can leverage their brand equity in terms of place branding. Competitiveness Review, 24(4), 293-305.

Hudak, K.C. (2019). Resident stories and digital storytelling for participatory place branding. Place Brand Public Diplomacy 15, 97-108.

Insch, A. (2011). Conceptualisation and anatomy of green destination brands. International Journal of Culture, Tourism and Hospitality, 5(3), 282-290.

Jacobsen, B.P. (2012). Place brand equity: a model for establishing the effectiveness of place brands. Journal of Place Management and Development, 5(3), 253-271. 
Judd, D. R., \& Fainstein, S. (Eds.). (1999). The tourist place. New Haven: Yale University Press.

Kaneva, N._(2011). Nation branding: Toward an agenda of critical research. International Journal of Communication, 5, 117-141.

Kavaratzis, M. \& Ashworth, G.J. (2005). Place branding: an effective assertion of identity or a transitory marketing trick? Sociale Geografie, 96(5), 506-14.

Kavaratzis, M., \& Ashworth, G. (2008). Place marketing: how did we get here and where are we going? Journal of Place Management and Development, 1 (2): 150-165.

Kavaratzis, M. (2009). What can we learn from city marketing practice? European Spatial Research and Policy, 16(1), 41-58.

Kavaratzis, M., Warnaby, G., \& Ashworth, G. (2014). Rethinking Place Branding: Comprehensive Brand Development for Cities and Regions. London: Springer.

Kavaratzis, M., \& Florek, M. (2021) Special Section: The future of place branding. Place Branding and Public Dipomacy 17, 63-64.

Keller, K. (1993). Conceptualizing, measuring and managing customer-based brand equity. Journal of Marketing. 57(1): 1-22.

Kleppe, I. A., Iversen, N. M., \& Stensaker, I. G. (2002) Country images in marketing strategies: Conceptual issues and an empirical Asian illustration. Journal of Brand Management, 10(1), 61-87.

Knight, J.G. (2011). New Zealand's 'clean green' image: Will GM plants damage it? Dunedin, New Zealand: Marketing Department, University of Otago.

Kolotouchkina, O. \& Seisdedos, G. (2018) Place branding strategies in the context of new smart cities: Songdo IBD, Masdar and Skolkovo. Place Branding and Public Diplomacy 14, 115-124.

Kotler, P., \& Gertner, D. (2002). Country as brand, product, and beyond: A place marketing and brand management perspective. Journal of Brand Management, 9(4): 249-261.

Kotler, P., Gertner. D., Rein, I., Haider, D. (2006). Marketing de Lugares. Como Conquistar Crescimento de Longo Prazo na América Latina e Caribe. Prentice Hall Brasil.

Kotler, P., \& Gertner, D. (2011). A place marketing and place branding perspective revisited. In N. Morgan, A. Pritchard \& R. Pride (Eds.), Destination brands: Managing place reputation (3rd ed., pp. 33-54). Oxford, UK: Butterworth-Heinemann.

Kotler, P., Haider, D., \& Rein, I. (1993). Marketing Places: Attracting Investment, Industry and Tourism to Cities, States and Nations. The Free Press, New York, NY.

Kotler, P., Kartjaya, H. \& Setiawan, I. (2021). Marketing 5.0 Technology for Humanity. John Wiley \& Sons, Inc. Hoboken, New Jersey. 
Kresl, P. (1995). The determinants of urban competitiveness: a survey. North American Cities and the Global Economy, p. 45-68. Thousand Oaks, CA: Sage.

Lucarelli, A. \& Berg, P.O. (2011) City Branding: A State-of-Art Review of the Research Domain. Journal of Place Management and Development, 4 (1): 9-27.

MacDonald, C. (2011). Expression and Emotion: Cultural Diplomacy and Nation Branding in New Zealand. (Master thesis), Victoria University, Wellington. Link

Mariutti, F. G. (2017). The placement of country reputation towards place management. Journal of Place Management and Development, 10(3): 240-253.

Mariutti, F. G., \& Giraldi, J. M.E (2019). How does a brand reputation-driven construct impact on country brand equity? A cross-national study of Brazil and China. Journal of International Consumer Marketing, 31(5): 408-428.

Mariutti, F. G., \& Giraldi, J. M. E. (2020). Country brand equity: The role of image and reputation. BAR-Brazilian Administration Review, 17 (3): 2-24.

Mariutti, F. G., \& Giraldi, J. M. E. (2021). Branding cities, regions and countries: a roadmap of place brand equity. RAUSP Management Journal, ahead of print, p.1

Mazumdar, B.T. (2021) Digital diplomacy: Internet-based public diplomacy activities or novel forms of public engagement? Place Branding and Public Diplomacy 17: 105-120.

McGibbon, J. (2006). Teppich-swingers and skibums: Differential experiences of ski tourism in the Tirolean Alps. In K. Meethan, A. Anderson \& S. Miles (Eds.), Tourism consumption and representation: Narratives of place and self (140-157). Wallingford, UK: CAB International.

Moilanen, T., \& Rainisto, S. (2009). How to brand nations, cities and destinations. London, United Kingdom: Palgrave Macmillan.

Morgan, N., Pritchard, A., \& Piggott, R. (2002). New Zealand, 100\% Pure: The creation of a powerful niche destination brand. Journal of Brand Management, 9(4/5), 335-354.

Moufahim, M., Humphreys, M., Mitussis, D., \& Fitchett, J. (2007). Interpreting discourse: A critical discourse analysis of the marketing of an extreme right party. Journal of Marketing Management, 23(5), 537-558.

Murphy, P. (2010). The intractability of reputation: Media coverage as a complex system in the case of Martha Stewart. Journal of Public Relations Research, 22(2), 209-237.

Ocke, M. (2013). Marca e imagem de um país: considerações sobre a Copa do Mundo de 2014 e a promoção do Brasil. Podium: sport, leisure and tourism review. 2(2): 95-120.

Ocke, M. (2018). O Produto ampliado dos lugares: uma perspectiva de marketing. Revista Interdisciplinar de Marketing. 2, 139-155. 
Ocke, M., \& Ikeda, A. A. (2014). Marketing de lugar: estado da arte e perspectivas futuras. Revista de Administração da USP, 49(4): 671-683.

Olins, W. (2002). Branding the nation - The historical context. Journal of Brand Management. 9(4/5), 241-269.

Olins, W., \& Hildreth, J. (2011). Nation branding: Yesterday, today, and tomorrow. In N. Morgan, A. Pritchard \& R. Pride (Eds.), Destination brands: Managing place reputation (3rd ed., 55-66). Oxford, UK: Butterworth-Heinemann.

Oliveira, M. O. R.; Stefanan, A. A.; Lobler, M. L. (2018). Brand equity, risk and return in Latin America, Journal of Product \& Brand Management, 27(5),557-572.

O'Shaughnessy, J., \& O'Shaugnessy, N.J. (2000). Treating the nation as a brand: Some neglected issues. Journal of Macromarketing, 20(1), 56-64.

Papadopoulos, N., \& Heslop, L. (2002). Country equity and country branding: Problems and prospects. Journal of Brand Management, 4(5), 294-314.

Papadoulos, N., Cleaveland, M., \& Bartikowski, M. (2018). Beyond country and brand origin: product/brand places associations and the role of place image in behavior and strategy. Guest Editorial. Journal of Product and Brand Management. 27(7), 733-734.

Papen, U. (2005). Exclusive, ethno and eco: Representations of culture and nature in tourism discourses in Namibia. In A. Jaworski \& A. Pritchard (Eds.) Discourse, communication and tourism. Clevedon, United Kingdom: Channel View Publications.

Passow, T., Fehlmann, R., \& Grahlow, H. (2005). Country reputation - from measurement to management: The case of Liechtenstein. Corporate Reputation Review, 7(4), 309-326.

Pedeliento, G., \& Kavaratzis, M. (2019). Bridging the gap between culture, identity and image: A structurationist conceptualization of place brands and place branding. Journal of Product \& Brand Management, 28 (30): 348-363.

Pennington, R. (2004). Brands, Culture and Semiotics (Revisited) in Creative Strategy Development. (Cardoso, P., \& Gaio, S. Eds). Publicidade e Comunicação Empresarial Perspectivas e Contributos. Porto, Edições Universidade Fernando Pessoa, p. 45-61.

Rainisto, S. (2003). Success factors of place marketing: A study of place marketing practice in northern Europe and the United States. Helsinki University of Technology.

Relph, E. (1976). Place and placelessness. London, UK: Pion.

Relph, E. (2004). Temporality and the rhythms of sustainable landscapes. In T. Mels (Ed.), Reanimating places: A geography of rhythms (111-121). Burlington, VT: Ashgate Publishing.

Rindova, V.P., Williamson, I.O., Petkova, A.P., \& Sever, J.M. (2005). Being good or being known: An empirical examination of the dimensions, antecedents, and consequences of organizational reputation. The Academy of Management Journal, 48(6), 1033-1049. 
Roper, J. (2010). CSR as issues management. Paper presented at the 60th Annual International Communication Association Conference, Singapore.

Roper, J. (2012). Environmental risk, sustainability discourses, and public relations. Public Relations Inquiry, 1(1), 1-19.

Scott-Smith, G. (2018). Special issue: the evolution of diplomacy. Place Branding and Public Diplomacy 14, 1-3.

Shields, R. (1991). Places on the margin: alternative geographies of modernity. London, UK: Routledge.

Shimp, T., Sharma, S. (1987). Consumer ethnocentrism: Construction and validation of the CETSCALE. Journal of Marketing Research, 24(8), 280-289.

Shimp, T., Saeed, S., \& Madden, T.J. (1993). Countries and their products: A cognitive structure perspective. Journal of the Academy of Marketing Science, 21(4), 323-330.

Shostack, G. (1977). Breaking Free from Product Marketing. Journal of Marketing, 41, 73 80

The Economist (2021). Brazil's dire decade. Jair Bolsonaro is not the only reason his country is in a ditch. The political system that helped him win office needs deep reform. Available at: https://www.economist.com/leaders/2021/06/05/jair-bolsonaro-is-not-the-only-reasonhis-country-is-in-a-ditch Access in June $3^{\text {rd }}, 2021$.

The Guardian (2021). Tens of thousands of Brazilians march to demand Bolsonaro's impeachment. Available at: https://www.theguardian.com/world/2021/may/29/tens-ofthousands-of-brazilians-march-to-demand-bolsonaros-impeachment.Access in June $3^{\text {rd }}$, 2021.

The New York Times (2021). 'Complete Insanity': Virus-Stricken Brazil Agrees to Host Soccer Tournament. Available at: https://www.nytimes.com/2021/06/02/world/americas/brazil-copa-america-soccertournament.html. Access in June $3^{\text {rd }}, 2021$.

The Place Brand Observer (2021). Place branding 2021: key priorities and trends to watch. Available at: https://placebrandobserver.com/place-branding-priorities-trends-2021/ Access in October $4^{\text {th }}, 2021$.

Van Ham, P. (2008). Place branding: the state of the art. Annals of the American Academy of Political and Social Science, 616(1), 126-149.

Vargo SL, Lusch RF (2008) Service-dominant logic: continuing the evolution. Journal Academy of Marketing Science, 36 (1):1-10

Volcic, Z., \& Andrejevic, M. (2011). Nation branding in the era of commercial nationalism. International Journal of Communication, 5, 598-618. 
Walsh, G., \& Wiedmann, K.P. (2008). Branding Germany: Managing internal and external country reputation. In K. Dinnie (Ed.), Nation branding: Concepts, issues, practice (154160). Oxford, United Kingdom: Butterworth-Heinemann.

Warnaby, G. (2009). Towards a service-dominant place marketing logic. Marketing Theory, 9(4), 403-423.

Warnaby G, Medway D (2013) What about the 'place' in place marketing? Marketing Theory, $13(3): 345-363$

Zenker, S. (2011). How to catch a city? The concept and measurement of place brands. Journal of Place Management and Development, 4(1), 40-52.

Zenker, S., \& Jacobsen, B. (2015). Inter-regional Place Branding: Best Practices, Challenges and Solutions. London: Springer. 


\title{
PLACE BRANDING BRASIL: AGENDA DE PESQUISA E PAINEL CONSULTIVO PARA O SÉCULO 21
}

\author{
Marco Antonio de Moraes Ocke \\ Universidade Federal de Santa Catarina - UFSC \\ Florianópolis, Santa Catarina- Brasil \\ marco.ocke@ufsc.br \\ Allan Augusto Platt \\ Universidade Federal de Santa Catarina - UFSC \\ Florianópolis, Santa Catarina- Brasil \\ allan.platt@ufsc.br
}

Objetivo: O objetivo do artigo é apresentar uma agenda de pesquisa e painel consultivo para acadêmicos e profissionais de marketing e branding sobre a área de place branding no contexto brasileiro.

Abordagem: Análise bibliográfica baseada no construto da imagem do lugar a partir de sua identidade competitiva e reputação com enfoque no conceito de nation branding e suas orientações econômica, política e crítica-cultural.

Resultados: Diretrizes e implicações sobre gestão e meta tendências em place branding. O âmbito da gestão consiste em uma estrutura formal de place branding para coordenar ações e stakeholders nas etapas de tomada de decisão; programa de marca guarda-chuva que beneficie diferentes setores da economia; métricas para monitorar resultados. As meta tendências estão relacionadas a orientação para marca verde como posicionamento competitivo; place branding no contexto da transformação digital; desafios e oportunidades para o place branding pós Covid-19.

Contribuição: $O$ trabalho destaca que uma forte liderança e planejamento eficiente na administração dos lugares devam prevalecer sobre medidas políticas equivocadas que enfraquecem o valor da marca, caso contrário, o desenvolvimento socioeconômico, a imagem do lugar e sua reputação correm o risco de serem continuamente comprometidos.

Relevância: Esta pesquisa chama a atenção, estimula o debate e sugere caminhos onde os princípios de place branding podem fornecer estímulos necessários para incentivar as lideranças brasileiras a cooperarem e colaborarem de forma mais consistente e eficiente no enfrentamento aos desafios do século 21 .

Palavras-chave: Place Branding. Agenda de pesquisa. Painel consultivo. Brasil.

\section{Como citar}

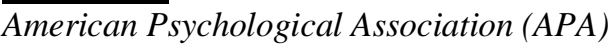

Ocke, M. A. de. M., \& Platt, A. A. (2022, jan./mar.). Place branding Brasil: agenda de pesquisa e painel consultivo para o Século 21. Revista Brasileira de Marketing - ReMarK, 21 (Num. Esp.), 30-65. https://doi.org/10.5585/remark.v21i1.20194. 


\section{Introducão}

A popularidade do place branding pode ser observada no aumento no número de artigos e periódicos nas últimas duas décadas, bem como livros e eventos acadêmicos sobre o assunto. O mesmo é observado no crescimento significativo do investimento em iniciativas de place branding em relação à competição por recursos, investidores, trabalhadores qualificados e visitantes entre locais de escala e complexidade variadas em todo o mundo e com projetos de branding realizados por empresas de consultoria. Esse fenômeno pode ser explicado pelo fato de o place branding não se limitar a uma área científica. Pelo contrário, é um campo de investigação multidisciplinar, envolvendo uma gama de perspectivas, diferentes pontos de partida, terminologias, estruturas teóricas e abordagens empíricas. Embora envolver uma variedade de disciplinas seja claramente vantajoso, há também um risco de desacordo em um campo que cruza fronteiras disciplinares. Nesse sentido, place branding e sua expansão para campos mais amplos e diversificados que possam se beneficiar de seu conhecimento é justamente o tratamento observado nos estudos contemporâneos.

Apesar da crescente presença do place branding na teoria e na prática, a análise de marcas de lugares está, de fato, ancorada em estratégias de marcas corporativas, o que significa que tanto a gestão de marca de lugares como a gestão de marcas corporativas possuem origem multidisciplinar, envolvem vários grupos de interesse, são dotadas de intangibilidade e complexidade, abrangem várias identidades e exigem desenvolvimento de longo prazo para alcançar resultados satisfatórios. Nesse contexto, tanto na teoria quanto na prática, são variadas as perspectivas sobre iniciativas que abordam os atributos formadores de marca de um lugar, bem como a participação de diferentes atores na construção e gestão desta marca, assim como uma diversidade de mercados-alvo. Como resultado, a aplicação do conceito de branding a lugares deve ser vista como uma forma distinta de branding. Sua essência multifacetada e os desafios de implementação decorrentes das políticas de gestão dos lugares permitem sugerir a necessidade de uma ampla compreensão e valorização do conceito.

A literatura de place branding demonstra que o conceito, como é entendido e atualmente aceito mundialmente, é o resultado de uma transição evolutiva: partindo da promoção do lugar ao planejamento do lugar resultando no conceito de marketing de lugar como é mais conhecido (Dinnie, 2004; Van Ham, 2008; Kavaratzis \& Ashworth, 2008; Ocke \& Ikeda, 2014). Essa transição pode ser agrupada sob perspectivas que não seguiram uma cronologia específica, possuem distinções relativamente indefinidas e estão integradas na essência do place branding. Ainda assim, cada estágio não foi substituído pelo seguinte, mas coexistem de modo que a 
qualquer momento, características de uma determinada fase podem ser encontradas atuando sobre o mesmo objeto. Pelas descobertas relacionadas à evolução do place branding (Kotler \& Gertner, 2002; Anholt, 2008; Gertner, 2011; Lucarelli \& Berg, 2011; Boisen, Terlouw, Groote \& Couwenberg, 2018), notam-se avanços, especialmente em termos de transição desde o conceito fragmentado de promoção e comercialização de lugares até o processo de planejamento estratégico de marketing, culminando na abordagem contemporânea de place branding, orientada para melhorar desde condições urbanas básicas as mais elaboradas, atrair investimentos nacionais ou estrangeiros, mão de obra qualificada, empresas, estudantes e visitantes.

Assim como o marketing de lugares, o place branding ainda enfrenta o ceticismo sobre a hipótese de que essas práticas aumentam a prosperidade de uma determinada região e, no longo prazo, criam condições para melhorar o bem-estar social. No cerne da crítica, está o argumento de que a fabricação de paisagens urbanas espetaculares e as imagens que as acompanham não apenas ensejam injustiças sociais e culturais, mas, de fato, servem como um subterfúgio para desviar a atenção dos cidadãos locais evitando a contestação popular de eventuais desigualdades (Hall \& Hubbard, 1998; Judd \& Fainstein, 1999; Eisinger, 2000). Esse viés controverso é potencializado pela falta de pesquisas baseadas em evidências que busquem estabelecer a eficácia do place branding, demonstrando ações e resultados significativos para o desenvolvimento socioeconômico. Em geral, a literatura apresenta grande quantidade de pesquisas qualitativas descritivas usando o método de estudo de caso, principalmente em regiões desenvolvidas na Europa (Kavaratzis, 2009; Go \& Govers, 2012), enquanto estimativas quantitativas de gastos e ROI para esforços de branding de lugares raramente estão disponíveis (Hart \& Stachow, 2010; Herezniak \& Morawska, 2015; Jacobsen, 2012).

Este cenário requer práticas e pesquisas em place branding para fornecer respostas, identificando e sugerindo formas eficazes de integração de métodos a serem utilizados como métricas para avaliar o retorno do investimento em tais iniciativas. No entanto, a incapacidade de justificar as despesas de place branding por meio de seu retorno financeiro continua sendo uma lacuna, parcialmente preenchida com a evolução do conhecimento e melhor compreensão do conceito e tem sido o foco mais recente entre praticantes e estudiosos do tema (Jacobsen, 2012; Herstein, Berger \& Jaffe, 2014; Florek \& Kavaratzis, 2014; Mariutti \& Giraldi, 2019, 2020, 2021). Nessa tentativa, o estado-da-arte do place branding tem se desdobrado em torno de estudos de place brand equity que reforçam a conexão com as estratégias de marcas corporativas, particularmente na noção de customer based brand equity-CBBE (Keller, 1993). 
Embora o conceito de valor da marca seja amplamente aceito, a noção de valor da marca aplicada aos lugares ainda tem muito a evoluir, pois sua compreensão no próprio espectro corporativo também é incerta, uma vez que existem variadas formas de apresentação e diferentes finalidades de medição e, como consequência, muitas abordagens têm sido propostas para estimar o valor da marca (Oliveira, Stefanan \& Lobler, 2018). Entre os estudos de marketing, principalmente em países emergentes, ainda não surgiu uma base teórica única e uniformemente aceita e, embora o mundo corporativo a reconheça como uma importante atividade de marketing, profissionais e pesquisadores ainda são desafiados a estimar e demonstrar resultados de valor de marca.

Outro importante elemento em torno de métricas de place branding é o conjunto de rankings competitivos para cidades, regiões e países, uma vez que um posicionamento favorável pode garantir orçamentos maiores para projetos atuais e futuros. Os rankings de maior credibilidade são aqueles produzidos por organizações conceituadas, estruturados por pesquisas robustas, demoradas e de alto custo financeiro (Jacobsen, 2012). Compreender a metodologia dos rankings é importante, pois cada um tem suas próprias limitações e, por isso, é relevante levar em conta diferentes estudos para determinar ou medir o sucesso de iniciativas em place branding. Além disso, a maioria dos rankings não é abrangente e limita-se a indicadores econômicos, enquanto características intangíveis de um lugar são difíceis de avaliar e capturar nos rankings. Nesse sentido, como afirma Anholt (2020), destaca-se o papel da imagem do lugar, especialmente para os países, uma vez que a percepção geral positiva de que um lugar contribui de alguma forma substancial para o mundo fora de suas próprias fronteiras pode valorizar sua atratividade e desenvolvimento socioeconômico no longo prazo.

De fato, um dos assuntos mais discutidos em estudos de place branding é o construto de formação da imagem do lugar a partir da sua identidade competitiva e, em certa medida, a conquista da reputação (Anholt, 2010b; Bell, 2016; Mariutti, 2017, Pedeliento, \& Kavaratzis, 2019). A literatura destaca que a execução do place branding depende de um mapeamento de recursos, diagnósticos de cultura e costumes para alcançar um entendimento profundo de como esses ativos podem beneficiar a imagem do local. Desta forma, todas as vantagens competitivas do lugar devem ser comunicadas de forma eficaz no sentido de consubstanciar uma imagem sólida de acordo com os seus atributos e alinhada com as especificidades de seus públicos. De acordo com Gaio e Gouveia (2007), essa perspectiva sugere que as estratégias de place branding operam em um continuum entre os ativos competitivos no âmbito territorial e o reconhecimento e interesse do público por essas características, ou seja, em um continuum entre 
a identidade e a imagem do lugar. Nesses termos, a identidade do lugar é um conceito emissor, que se refere a um fenômeno dinâmico entre a dimensão política, tangíveis territoriais e resultados das interações socioeconômicas e tecnológicas das pessoas com o espaço físico, enquanto que a imagem é um conceito receptor porque reflete o modo como é percebido pelo público (Dinnie, 2015). Por outro lado, a reputação do lugar difere da imagem do lugar, pois é centrada em impressões construídas em torno de inúmeras imagens e ações agregadas ao longo do tempo (Passow, Fehlmann, \& Grahlow, 2005). Desta forma, o place branding como uma ferramenta de construção de reputação é essencialmente um esforço cumulativo de longo prazo baseado em percepções alinhadas entre mercados internos e externos.

Uma reflexão fundamental sobre a complexidade do place branding está na difícil tarefa de descrever a natureza dos lugares, uma vez que se são construções sociais incorporadas a um espaço físico onde ocorrem diferentes atividades. Os lugares são entidades continuamente reconstruídas por meio de processos administrativos, sociais e políticos que atribuem significados e desencadeiam emoções que influenciam a forma como as pessoas percebem, vivenciam e valorizam o ambiente (Cheng, Kruger, \& Daniels, 2003; Relph, 2004, Campelo, Aitken, Gnoth, \& Tomilho, 2009). Alinhada ao pressuposto de lugar no sentido geográfico de vilas, cidades, regiões e países inteiros (Hanna \& Rowley, 2008), a literatura de marketing de serviços nos fornece importantes contribuições de conceitos como o produto aumentado (Shostack, 1977) e a lógica dominante em serviços (Vargo \& Lusch, 2008; Warnaby, 2009; Warnaby \& Medway 2013). A economia de serviços e os atributos intangíveis ganharam espaço na composição do produto local, incluindo elementos e particularidades que poderiam proporcionar uma maior oferta de oportunidades para os mercados atuais e potenciais (Ocke, 2018). Esse construto constitui uma melhor visualização e compreensão particular do lugar como um composto físico imbuído de significado social, resultando em uma combinação de muitos aspectos diferentes que contribuem para a distinção do lugar.

Em termos de dimensão e complexidade dos lugares, países são considerados uma importante área de estudos em place branding. Do ponto de vista político e crítico-cultural, o nation branding pode ser caracterizado por um enfoque interno onde é percebido principalmente como uma forma de redefinir as nações tanto por meio da ideologia quanto da práxis. A literatura atribuída à abordagem política considera o nation branding como uma forma de propaganda para construir e gerenciar a reputação, promovendo a economia, a cultura, a história e a geografia de um país. No entanto, a maioria das definições de nation branding são atribuídas à perspectiva econômica, que, em termos de números, é a mais comum em 
publicações acadêmicas (Olins, 2002; Kotler \& Gertner, 2002; Anholt, 2007; Aronczyk, 2009; Govers \& Go, 2009; Fan, 2010; Kaneva, 2011; Dinnie, 2015). A abordagem econômica discute o nation branding como um meio estratégico para aumentar a vantagem competitiva de um país em um cenário global com o objetivo de promover a nação junto a seus mercados, torná-la mais atraente e apoiar os esforços de diplomacia. Como resultado, nation branding é considerado uma metáfora da eficácia com que os países competem entre si pela percepção favorável em relação às exportações, governança, turismo, investimento e imigração, cultura e patrimônio e pessoas (Anholt, 2020). Nesse sentido, a ênfase principal recai sobre o imperativo econômico da competitividade e medidas para garantir uma reputação favorável entre os mercados-alvo.

Após ter retratado algumas importantes distinções e avanços ao longo dos anos, este trabalho destaca a importância do place branding no contexto brasileiro, uma vez que a maioria das contribuições desta área é amplamente originada da Europa, América do Norte e Ásia (Van Ham, 2008; Gertner, 2011 ; Dinnie, 2015), enquanto no Brasil e em demais países da América Latina, as discussões tendem a se concentrar apenas na marca para destinos turísticos destination branding (Kotler, Gertner, Rein \& Haider, 2006) em vez de construir uma abordagem abrangente e mais profunda para incorporar elementos de branding para aprimorar as estratégias de cada país (Zenker \& Jacobsen, 2015). Nesse contexto e a fim de atender a edição especial da Revista Brasileira de Marketing, o objetivo deste artigo é apresentar uma agenda de pesquisa e painel consultivo para acadêmicos, profissionais de branding e profissionais de marketing a fim de chamar a atenção, estimular o debate e sugerir caminhos onde os princípios de place branding possam fornecer conhecimentos para incentivar as lideranças brasileiras a cooperarem e colaborarem de forma mais consistente e eficiente para enfrentar alguns desafios presentes no século 21 (Harari, 2019). Neste sentido, o trabalho conjunto, consciente e orquestrado entre acadêmicos e profissionais de diferentes setores para discutir iniciativas de place branding pode trazer resultados positivos e colaborar com a comunidade latino-americana.

Para atingir seus objetivos, o artigo apresenta uma análise bibliográfica baseada em uma revisão de literatura abrangendo dois pilares principais do place branding: o nation branding, em suas perspectivas econômica, política e crítica-cultural; a construção da imagem do lugar, a partir do continuum da identidade competitiva à conquista da reputação. Realizada a partir do exame de artigos publicados em periódicos de alto impacto na área de place branding e livros escritos por autores reconhecidos internacionalmente nas últimas duas décadas, a análise bibliográfica oferece um conjunto substancial de conceitos para conduzir a discussão do artigo 
que delineia a urgência do conhecimento em place branding no contexto brasileiro revisitando brevemente aspectos da identidade, imagem e reputação do Brasil, especialmente focado em suas perspectivas políticas e econômicas nos últimos anos. Em seguida, é apresentada uma estrutura de agenda e painel consultivo centrados na perspectiva de nation branding no contexto brasileiro, valorizando dois corolários principais: gestão e tendências de place branding.

O composto de gestão de marca consiste em formas efetivas de organização formal para coordenar ações e atores reconhecendo a participação de stakeholders nas etapas de tomada de decisão; a cooperação entre governantes e lideranças para alcançar objetivos comuns dentro de um programa de marca guarda-chuva para beneficiar os diferentes setores da economia comercializados de forma consistente dentro do escopo de nação que fazem parte; aplicação de métodos integradores para medir e avaliar os resultados dos esforços em place branding. As implicações em relação às meta tendências em place branding buscam guiar estudos futuros e referem-se a uma orientação e posicionamento de marca verde como um ativo competitivo; place branding em um contexto de transformação digital onde a rede expandida de tecnologia da informação e comunicação permite a conexão de lugares, pessoas e organizações orientadas por dados; place branding pós Covid-19 incluindo desafios e oportunidades para a reconstrução da economia e melhoraria da imagem das localidades. Espera-se, com essas diretrizes, gerar o entendimento de que uma forte liderança e planejamento eficiente para o desenvolvimento do país devem prevalecer sobre medidas políticas equivocadas que enfraquecem o valor de sua marca, caso contrário, o desenvolvimento socioeconômico do país, sua imagem e reputação correm o risco de serem continuamente comprometidos.

\section{Nation branding}

O conceito de nation branding não são se difere muito de place branding uma vez que a literatura o discute como um meio estratégico para aumentar a vantagem competitiva de um país. Embora a maioria das marcas-país seja criada com base na cultura e tradições existentes e, portanto, até certo ponto justificada, elas tendem a ser orientadas para o mercado, o que significa que podem ser tanto um canal positivo para incentivar cidadãos responsáveis quanto uma ferramenta de propaganda que justifica preocupações, como o potencial impacto em diferentes grupos de interesse. Visto como um conjunto de ideias, emoções ou coleções de percepções, gerenciar uma marca-país é um processo amplamente intangível e socialmente construído, uma vez que uma mistura multidimensional de elementos fornece à nação diferenciação e relevância culturalmente fundamentadas. Nesse cenário, a literatura sobre o 
nation branding tende a apoiar o conceito ou argumentar contra ele, em grande parte dependendo dos pressupostos ontológicos subjacentes em relação ao poder social e à identidade nacional.

Embora a literatura de place branding e nation branding nem sempre faça distinção rigorosa entre os dois termos, uma diferença sutil pode ser encontrada em relação ao foco em mercados internos versus externos. Como descrevem Olins e Hildreth (2011), ao contrário do foco externo do place branding, o nation branding, pelo menos do ponto de vista político ou cultural-crítico, está associado à construção da nação internamente, onde é percebido principalmente como uma forma reconstituir as nações tanto pela ideologia quanto pela práxis. No entanto, como salientam Moilanen e Rainisto (2009), o foco externo expresso pela abordagem econômica das marcas-país funde os dois conceitos em seu propósito quase idêntico de promover uma determinada localização geográfica a um público-alvo, tornar um lugar mais atraente e apoiar esforços de diplomacia.

Considerando uma extensa revisão na literatura de nation branding, observa-se significativa variação na forma como o conceito é apresentado e discutido. Referindo-se a 186 publicações acadêmicas examinadas, Kaneva (2011) conclui que uma ampla distinção pode ser encontrada entre as abordagens político-cultural-crítica e a perspectiva técnico-econômica. Enquanto os estudiosos que exploram o nation branding a partir de uma perspectiva cultural-crítica o entendem como uma forma de reconstituir nações tanto por meio da ideologia quanto da práxis, a literatura atribuída à abordagem política vê o nation branding como uma forma de propaganda, ou, em certa medida, como uma forma inofensiva de construir e gerenciar a reputação, promovendo a economia, cultura, história e geografia de um país. No entanto, a maioria das definições de nation branding pode ser atribuída à perspectiva econômica, que é a mais comum em publicações acadêmicas, pois prevalece o uso explícito da linguagem de mercado.

\subsection{Perspectiva econômica}

Como uma área emergente, o nation branding vem sendo impulsionado principalmente por profissionais de marketing e branding. A prática demonstra que há uma falta de preocupação com a tendência crescente dos governos em gastar maiores quantias de recursos públicos em propaganda - em outras palavras, mensagens pagas informando ao mundo sobre os ativos e conquistas de seus países e cidades, na esperança de que isso melhore suas imagens. Os gestores de marca-lugar geralmente contam com publicidade, relações públicas, vendas, marketing online e outros canais para comunicar criativamente a ideia de um lugar. Inspiradas na era da promoção de lugares, essas técnicas não funcionam isoladas, pois os lugares são julgados pelo que fazem, não pelo que dizem sobre si mesmos (Gold \& Ward, 1994; Anholt, 2007; Dinnie, 2008; Kavaratzis \& Ashworth, 2008). 
Nesse sentido, o princípio básico de uma identidade nacional competitiva precisa ser consistente e substancialmente comprovado pelo comportamento real, no longo prazo. Isso sugere que esse efeito não pode ser alcançado apenas por mensagens persuasivas e pode não haver correlação entre a imagem de um país e o valor que ele gasta em comunicações de marketing exclusivamente.

De acordo com Anholt (2010a, 2020), autor amplamente credenciado por ter cunhado o termo, a maneira como o nation branding está sendo usado na literatura e na prática é enganosa, pois sugere que uma nação pode ser passível de branding em sua essência. O autor afirma que nation branding é apenas uma metáfora da eficácia com que os países competem entre si por uma percepção favorável no que diz respeito às exportações, governança, turismo, investimento e imigração, cultura e patrimônio, ou pessoas. Como outros autores que compartilham a mesma perspectiva sobre nation branding (Olins, 2002; Kotler \& Gertner, 2002; Bell, 2005; Aronczyk, 2009; Govers \& Go, 2009; Fan, 2010; Dinnie, 2015), a ênfase principal está na competição e o propósito do branding de um país é garantir uma reputação favorável junto ao público-alvo, ou seja, o imperativo econômico. Nessa ótica, o nation branding é visto como um meio para construir e manter a vantagem estratégica de um país com o objetivo de crescimento econômico e uma ferramenta para aumentar a vantagem competitiva, buscando alimentar sua hegemonia no mercado internacional.

A intenção de gerir uma marca-país para garantir reputação favorável entre os diferentes mercados, não só reflete na imagem do próprio país, mas também em suas empresas, produtos e serviços, fazendo com que pareçam preferíveis aos olhos dos consumidores. Shimp, Saeed e Madden (1993) utilizaram a expressão “country equity” para descrever o valor emocional que os consumidores associam a um país. Isso acontece quando o nome de um país os ajuda a avaliar os produtos vindos de lá e a tomar suas decisões de compra. Mesmo quando um país não administra conscientemente sua marca, as pessoas guardam uma imagem dele que resulta de inúmeras características e determina atitudes e comportamentos em relação ao lugar e que pode ser suscitada pela simples menção de seu nome. Isso tem a capacidade de influenciar decisões em relação a compras, investimentos, migração e viagens (Carroll \& McCombs, 2003; Dinnie, 2008). Nesse contexto, o conceito de marca-país vem sendo analisado como forma de fortalecer a produção nacional, tornando um lugar mais competitivo no mercado internacional, agregando valor às marcas do país na competitividade global e protegendo-as dos efeitos negativos advindos das políticas governamentais nacionais e internacionais. (Kotler \& Gertner, 2011).

Conforme definição proposta por Aaker (1991), valor de marca associada ao country equity é um conjunto de ativos e passivos vinculados à marca, seu nome e símbolo, que são 
somados ou subtraídos ao valor fornecido por um produto ou serviço. Apesar do objetivo das marcas globais ser vender seus produtos e serviços e não seu local de origem, ainda que associado a ações de alavancagem, o valor emocional resultante da associação dos consumidores de uma marca com seu país de origem pode somar ou subtrair a valor percebido de um produto (Shimp \& Sharma, 1987). Em outras palavras, os estereótipos que os consumidores têm de países e pessoas podem operar como avaliações de marcas ou produtos específicos e determinar, em certa medida, as intenções de compra e o comportamento do consumidor (Gnoth, 2002; Gudjonson, 2005; Roper, 2010). No entanto, é fundamental ressaltar que a atividade de beneficiar um lugar, principalmente um país, utilizando a ferramenta de branding exclusivamente para apoiar marcas em busca de competitividade, não pode ser considerada place branding. Pesquisando a imagem de um país no cenário internacional, abrangendo dimensões políticas, econômicas e culturais, Fan (2010) destaca que o nation branding transcende o propósito mais restrito de marca-lugar assim como o efeito país de origem para promover indústrias e mercados específicos. A autora sugere que o nation branding não se trata apenas de promover os interesses de determinadas indústrias e esse tipo de estratégia de valor agregado é uma forma de co-branding onde os nomes e atributos das localidades podem agregar valor extra aos produtos, serviços e marcas vendidas no exterior. Por outro lado, o inverso também pode ocorrer, ou seja, um país pode ser promovido com o auxílio de marcas corporativas e produtos físicos que podem gerar associações positivas em relação ao lugar de origem, colaborando com sua imagem global.

Os avanços encontrados na literatura de place branding têm descrito as diferenças entre a promoção tradicional de setores e produtos de um país, como comércio, investimento e turismo, e a tentativa de melhorar a imagem nacional. Embora custosa, mas relativamente direta e comprovadamente eficaz, a promoção do lugar é, de fato, uma questão de informar os mercados em potencial sobre o que está em oferta e usar mídia e mensagens persuasivas. Por outro lado, aprimorar a imagem do lugar como um todo é uma abordagem baseada na formulação de políticas públicas muito mais difícil de alcançar, levando muito mais tempo e dificilmente mensurável. Como aponta Anholt (2020), se a contribuição de um país para os bens comuns globais for suficientemente inovadora, consistente, relevante e comprovadamente eficaz para as reais necessidades das pessoas e do planeta, a estratégia de nation branding não precisa investir grandes quantias em publicidade, relações públicas, agências de branding ou grupos de mídia, uma vez que a publicidade orgânica irá alavancar a imagem do lugar junto aos diversos stakeholders da nação que passam a tornarem-se embaixadores da marca. 


\subsection{Perspectiva política}

Semelhanças com a perspectiva econômica podem ser encontradas nas contribuições de nation branding sob a perspectiva política compreendida como esforços coordenados do governo para gerenciar a imagem de um país a fim de promover o turismo, o investimento e as relações internacionais (Volcic \& Andrejevic, 2011). A literatura atribuída à abordagem política destaca o nation branding como um formato potencializado de propaganda ou, em outras palavras, uma maneira inofensiva de construir e gerenciar a reputação do país por meio da promoção de sua cultura, história e geografia compondo uma estrutura mais progressiva de patriotismo do que suas contrapartes antagônicas (Aronczyk, 2009). Estudiosos pertencentes a essa perspectiva política sobre nation branding são críticos em relação à ênfase no posicionamento de mercado e competitividade, enfatizando que as tentativas de dotar as nações de branding pode ser arriscado e até contraproducente, pois podem criar desconfiança nos esforços para conquistar a preferência de determinados públicos (MacDonald, 2011).

Outra observação é a gestão de marca-país descrita como uma poderosa ferramenta política, especialmente para pequenas nações periféricas ávidas por fortalecer sua posição econômica e competir contra a influência econômica, financeira ou militar de nações empoderadas (Volcic \& Andrejevic, 2011). Os autores sugerem que em uma era de globalização capitalista, branding e competição comercial podem se tornar a continuação de uma guerra por outros meios. Para evitar equívocos e conflitos relacionados à complexidade e poder de diferentes nações, os estudos políticos avançaram em direção ao conceito de public diplomacy que está intimamente ligado ao nation branding, embora sua importância em nível de estadosnação, cidades e regiões encontra-se em crescimento (Scott-Smith, 2018). No ponto de vista das relações internacionais, Govers (2020) afirma que a public diplomacy trata da comunicação com os mercados-alvo estrangeiros para estabelecer um diálogo destinado a informar e influenciar e juntamente com o place branding como área de convergência, refletir os processos pelos quais uma nação conduz a política externa por meio do envolvimento direto com o público estrangeiro em busca de gestão de reputação e influência de mercados internacionais.

\subsection{Perspectiva Crítica-Cultural}

Os estudos que adotam uma abordagem crítica-cultural para o conceito de nation branding tendem a se concentrar em suas implicações para identidades nacionais, relações de poder social e definição de agenda (Kaneva, 2011). Pesquisadores investigam como o marketing e branding podem influenciar a esfera social e como essas práticas alteram as percepções das pessoas sobre si 
mesmas e sua identidade nacional, ligando a dimensão discursiva do nation branding às ideias construtivistas de nacionalidade. Butler (1998) e Knight (2011) argumentam que, em vez de desenhar uma imagem adequada da história, natureza e tradições de um lugar, o nation branding enfatiza versões distorcidas para se encaixar nas preferências dos mercados-alvo. As consequências potenciais de promover uma imagem distorcida ou idealista de uma nação podem ser problemáticas, uma vez que gera e perpetua uma mentira na qual os moradores devem viver; roubando assim a autenticidade de sua cultura (Fesenmaier \& MacKay, 1996). Seguindo essa abordagem, a própria prática de marketing e branding deve ser tratada com cautela, uma vez que o marketing não é um meio neutro e isento de comercializar produtos e serviços para satisfazer necessidades. Em vez disso, por meio do uso de símbolos específicos, discursos e práticas ideológicas, o branding molda ativamente as relações sociais, por exemplo, concedendo ao consumo material um papel central na vida das pessoas (Moufahim, Humphreys, Mitussis \& Fitchett, 2007).

Compreendido como um compêndio de discursos e práticas que visam à reconstituição da nacionalidade por meio de paradigmas de marketing e branding, o nation branding sob a perspectiva crítica-cultural revela um certo modo de pensar o papel de uma nação e de seu povo, que busca por mobilização em prol do desenvolvimento econômico (Kaneva, 2011). Ao fazê-lo, segue a lógica da governança neoliberal na medida em que combina as obrigações da cidadania com as responsabilidades e riscos do empreendedorismo (Volcic \& Andrejevic, 2011). As ligações cada vez mais estreitas entre nation branding e as políticas públicas, por meio de incentivo, financiamento, gestão e controle ativos por meio de organizações governamentais, levaram a um campo crescente de análises críticas da marca-país, nesse sentido entendida como uma forma de governança por meio de imperativos de mercado. Dessa forma, Volcic e Andrejevic (2011) declaram que o ambiente político se tornou uma comunidade de marca e os governos os principais profissionais de marketing responsáveis por alinhar políticas externas e domésticas em estratégias de marca-país.

\section{Identidade, imagem e reputação}

Como um dos mais extensos temas de pesquisa em place branding, a imagem dos lugares é amplamente compreendida como um construto desenvolvido a partir da gestão dos ativos de sua identidade competitiva e, em certa medida, da conquista de reputação do lugar. As principais contribuições dos estudiosos destacam que a execução assertiva do place branding depende de um mapeamento de recursos necessários, diagnósticos de cultura e costumes e um profundo entendimento de como esses ativos podem beneficiar a imagem do lugar. Além disso, a oferta de serviços básicos, infraestrutura, condições de superestrutura e o 
conjunto de fatores positivos percebidos pelos principais mercados devem ser prioritários na busca por posicionamento competitivo no mercado global e alcançar uma reputação sólida no longo prazo. O custo e a eficácia das estratégias de gestão em place branding dependem da imagem do lugar em função de como diferentes públicos formam percepções sobre ele, portanto, a atividade de gestão deve diagnosticar a identidade competitiva e projetar uma série de imagens coerentes e consistentes para todos os seus grupos de interesse. As vantagens competitivas de devem ser comunicadas de forma eficaz para construir e gerenciar uma imagem sólida, de acordo com seus atributos e alinhada às especificidades de seus públicos. No entanto, existem diferenças inevitáveis na forma como esses elementos são percebidos pelos diversos mercados. Portanto, as ações de place branding devem considerar as manifestações tangíveis e intangíveis de sua realidade, veiculadas por meio de seus atributos e vetores de atratividade para que possam ser percebidas por uma ampla gama de audiência.

\subsection{Identidade dos lugares - place identity}

Ao longo da década de 1990 havia uma preocupação em identificar atributos relacionados à capacidade das indústrias e a forma como essa força influenciava diretamente na competitividade dos lugares. Além disso, outro viés de pesquisa concentra-se em respostas mais específicas, incluindo interações entre políticas governamentais e autoridades públicas locais, além de respostas organizacionais entre instituições públicas e parcerias locais (Fainstein, 1990). Isso fez com que as ações e relações governamentais fossem dotadas de significativa importância na construção de uma identidade competitiva. Nesse sentido, estudiosos buscaram operacionalizar os determinantes da identidade de marca dos lugares (Kresl, 1995; Grabow, Henkel \& Hollbach, 1995). Como apontou Hall (1998), na busca por diferentes e novas formas de garantir que um lugar seja mais competitivo, os rankings globais e nacionais começaram a ganhar mais importância, o que pode ser observado no avanço dos índices e rankings de place branding ao longo dos anos seguintes (Kotler et.al, 2006; Anholt, 2006, 2007; Fetscherin, 2010; Zenker, 2011). A economia de serviços e os atributos intangíveis ganharam espaço na composição da identidade da marca-lugar, incluindo elementos e particularidades que poderiam proporcionar uma maior oferta de oportunidades para os mercados atuais e potenciais.

Place branding, em sua dimensão funcional e simbólica, tem a capacidade de substanciar e valorizar a identidade do lugar, promovendo a identificação e envolvimento com os públicos e, simultaneamente, distinguindo-o das localidades concorrentes. Nesse contexto, 
as estratégias de place branding atuam em um continuum entre os atributos do território e o reconhecimento e interesse do público por essas características, ou seja, em um continuum entre a identidade e a imagem do lugar (Gaio \& Gouveia, 2007). Enquanto a identidade é um conceito emissor, que se refere a um fenômeno dinâmico entre a dimensão política, os tangíveis territoriais e os resultados das interações socioeconômicas e tecnológicas das pessoas com o espaço, a imagem é um conceito receptor porque reflete a forma como é percebida pelo público (Dinnie, 2015).

Este continuum baseia-se na simplificação de um grande número de crenças, impressões e informações ligadas a um lugar, que inclui fatores como sua história, geografia, arte, música e cidadãos famosos. Zenker \& Jacobsen (2015) indicam que aspectos geográficos como clima, natureza e localização são fatores decisivos na construção dos atributos que formam a imagem de uma nação, estado, cidade ou comunidade, mas não atuam por conta própria. Os autores acrescentam que outros canais de promoção, como os setores econômicos determinam parcialmente as vantagens competitivas do lugar juntamente com sua indústria, serviços, recursos e legislação, e devem ser levados em consideração ao vincular identidade e imagem dos lugares. Nesse sentido, a economia da localidade, juntamente com sua cultura e características de seu povo, atua como uma exposição ao cenário mundial, determinando ritmos de desenvolvimento e prosperidade, assim como a política é parte integrante dessas relações e um importante canal de informação por meio da diplomacia e influência em diversas dimensões que compõem a imagem do lugar (Anholt, 2010b).

Os lugares possuem identidades baseadas em atributos patrimoniais, econômicos, tecnológicos, relacionais, sociais e simbólicos que estão no cerne dos processos de construção da imagem dos territórios (Van Ham, 2008). Segundo Kotler, Haider e Rein (1993), é a estrutura de conhecimento relativa a um lugar, ou seja, a identidade do lugar é o conjunto de elementos que lhe conferem personalidade, em outras palavras, lhe conferem uma imagem. Ashworth e Kavaratzis (2008), numa perspectiva processual, esclarecem a gestão da marca do lugar como um esforço para selecionar atributos da identidade local, traduzi-los e comunicá-los por meio de uma estratégia de posicionamento, materializada em símbolos, argumentos e técnicas de comunicação que distinguem o lugar dos concorrentes e representam valor para todos os seus públicos. As técnicas utilizadas pelas localidades para identificar e comunicar os seus atributos e valor agregado constituem uma ferramenta eficaz para a competitividade dos lugares (Govers \& Go, 2009). Anholt (2007), no entanto, enfatiza que os atributos dos lugares são difíceis de definir, incluindo sua imagem e as inúmeras associações que evocam em oposição a bens e 
serviços. Nesse contexto, as localidades precisam projetar uma imagem forte e substancial para atrair potenciais compradores por meio de um posicionamento único e diferenciado (Giraldi \& Ikeda, 2009).

Kavaratzis, Warnaby e Ashworth (2014) destacam três formas de comunicar as expressões de um lugar: comunicação primária, que inclui a arquitetura e os aspectos físicos da localidade; comunicação secundária, que inclui informações formais por meio de canais oficiais, bem como ações de publicidade e relações públicas; comunicação terciária, que se refere à comunicação boca a boca alavancada pela mídia e principalmente pelos residentes locais. No entanto, os autores ressaltam que a gestão da imagem de um lugar requer maior profundidade analítica, portanto, um estudo dos efeitos negativos e positivos que sua divulgação pode trazer para o próprio lugar bem como as comunidades envolvidas e um planejamento de longo prazo que minimize os efeitos negativos e até garanta a manutenção das atrações são os principais ativos nas ações de place branding.

\subsection{Imagem dos lugares - place image}

Kavaratzis \& Ashworth (2005) sugerem que lugares podem ser passíveis de branding se suas características puderem se diferenciar de uns dos outros. Neste contexto, um nome é uma marca e, à semelhança de outros tipos de ofertas, as pessoas podem partilhar um conjunto consistente de características, imagens ou emoções quando recordam ou experienciam uma determinada localidade (Govers \& Go, 2009). O processo de construção da imagem do lugar é baseado em um conjunto de signos e experiências que individualmente podem não ser decisivos na opinião do receptor, mas como um todo tornam-se fundamentais para a construção de um juízo de valor. Consequentemente, a imagem de um lugar é um determinante básico de como os cidadãos e as empresas reagem a ela, portanto, um lugar deve buscar gerenciar sua imagem de forma assertiva. Dinnie (2015) refere que mesmo quando um lugar não gerencie conscientemente sua marca, as pessoas mantêm uma imagem que resulta de inúmeras características e determina atitudes e comportamentos em relação a ele e que pode ser suscitada pela simples menção do seu nome, influenciando decisões de compras, investimentos, realocação e viagens.

Haider, Kotler e Rein (1994) afirmam de forma clara e objetiva a possibilidade de um lugar promover suas qualidades e gerenciar sua imagem. Segundo os autores, a competição por investimentos torna imperativo que os lugares cuidem de sua imagem para se tornarem uma opção competitiva. Pennington (2004) destaca que a gestão da marca do lugar potencializa um 
vínculo sinérgico com o desenvolvimento econômico, contribuindo tanto para atrair e reter pessoas e empresas quanto para favorecer o co-branding ao estender a imagem do lugar e os atributos da marca a produtos e clusters locais promovendo novas e múltiplas centralidades no território. Pesquisas empíricas (Rainisto, 2003; Dinnie, 2007; Anholt, 2008) mostram que as imagens que as localidades projetam são importantes indicadores extrínsecos na avaliação de seus produtos e oportunidades de investimento, não deixando dúvidas de que as marca-lugar deve ser posicionada de forma consciente.

Conforme proposto por Relph (1976), as imagens dos lugares não são formadas simplesmente em termos de padrões de características físicas e observáveis, nem apenas como produto de atitudes, mas como uma combinação indissociável dessas características. Além disso, as imagens dos lugares são diversas e multifacetadas, parciais e muitas vezes exageradas ou subestimadas (Shields, 1991). Enquanto Haider et al. (1994) descrevem a imagem de um lugar como a soma de crenças, ideais e impressões que as pessoas têm em relação a um determinado lugar, Zenker (2011) define a imagem de um lugar como uma rede de associações na mente dos consumidores com base no visual, verbal e expressões comportamentais de um lugar, que são representadas nos objetivos, comunicação, valores e a cultura geral do produto do lugar. As imagens dos lugares são ainda moldadas pela cultura, história e até cidadãos famosos (Florek \& Insch, 2008; Hart \& Stachow, 2010; Murphy, 2010; Dinnie, 2015). Nesse contexto, os lugares são cercados por complexos simbólicos de imagens provenientes de diversas fontes e muitas vezes sujeitos a discursos concorrentes (Papen, 2005; McGibbon, 2006).

Vários estudos enfatizam a imagem do lugar como um lado controverso do place branding, uma vez que as percepções sobre os lugares tendem a ser vagas (O'Shaughnessy \& O'Shaugnessy, 2000), e podem não refletir exatamente as realidades locais (Anholt, 2007; Walsh \& Wiedmann, 2008). As percepções derivadas do processo de generalização para uma classe inteira de objetos a partir de um número limitado de observações não são facilmente alteradas, pois, uma vez estabelecidas, as imagens centrais nas quais esses estereótipos se baseiam tendem a ser persistentes e estáveis (Coyle \& Fairweather, 2005). Nesse sentido, apesar de associações e experiências com lugares específicos provavelmente diferirem devido a necessidades e propósitos distintos (Hankinson, 2004; Warnaby, 2009; Hart \& Stachow, 2010), quando compartilhadas e amplamente aceitas entre os públicos, suas imagens podem se tornar estereotipadas para esses lugares (Boisen, Terlouw, \& Bouke, 2011). Além disso, as representações da mídia desempenham um papel crucial no contexto da imagem dos lugares 
como parte principal pela qual a informação é disseminada e pelas formas como são representadas, influenciando as imagens dos lugares junto a seus mercados (Carroll \& McCombs, 2003; Murphy, 2010; Boisen et al., 2011).

Outro aspecto da natureza controversa da imagem de lugar é que ela pode desenvolver um significado além ou mesmo independente do que inicialmente pretendiam seus gestores (Govers \& Go, 2016). Ou seja, isso representa que o conhecimento, a experiência, as expectativas, as crenças, os valores e os motivos do consumidor podem resultar de uma interpretação bem diferente daquela pretendida pelo emissor da mensagem (Kavaratzis, Warnaby \& Ashworth, 2014). Esses argumentos encontram algum suporte significativo nos pensamentos de Shields (1991) sobre imagens de lugares como os vários significados discretos associados a lugares, independentemente de seu caráter na realidade. Além disso, do ponto de vista da imagem do lugar como domínio público, pode ser manipulada e explorada por qualquer parte interessada em atingir determinadas finalidades (Botschen, Promberger, \& Bernhart, 2017) e, além disso, as imagens dos lugares são instáveis, dinâmicas e influenciadas por fatores impossíveis de serem totalmente controlados (Papadopoulos \& Heslop, 2002; Murphy, 2010; Kotler \& Gertner, 2011).

\subsection{Reputação dos lugares - place reputation}

Assim como o place branding e a reputação do lugar não são facilmente dissociados, a imagem do lugar em si não pode ser considerada isoladamente como a pedra angular na construção da reputação. Nesse sentido, a promoção do lugar implementada de forma isolada e não aderindo a uma estratégia mais ampla de gestão provavelmente não terá efeitos de longo prazo para a localidade e poderá trazer resultados apenas temporários (Bell, 2016). Como afirma Mariutti (2017), um lugar deve primeiro ser aperfeiçoado por meio de gestão e desenvolvimento antes de alcançar uma reputação positiva, ou seja, gestão e reputação devem estar alinhadas para desenvolver e melhorar para alcançar prosperidade sustentável. Entendida como o agregado de imagens do lugar ao longo do tempo (Passow, Fehlmann, \& Grahlow, 2005), a reputação difere da imagem do lugar, pois é centrada em impressões de longo prazo construídas em torno de inúmeras imagens e ações. Enquanto a reputação opera como uma construção de compreensão mais profunda do place branding, a imagem torna-se um elemento central para a reputação de um lugar sendo fundamentada em entendimentos espontâneos (Mariutti \& Giraldi, 2020). 
Em um contexto organizacional, de acordo com Rindova, Williamson, Petkova e Sever (2005), a reputação geralmente é atribuída a duas dimensões: primeiro, como os stakeholders percebem a qualidade de atributos específicos no contexto da empresa e, segundo, o grau em que um organização é reconhecida coletivamente. Além disso, do ponto de vista dos negócios, a reputação tem sido definida como a combinação da proeminência pública de uma empresa o nível em que uma organização é reconhecida em larga escala e saliente nas mentes das partes interessadas, sua estima pública - e o grau em que a empresa o público aprecia, confia, admira e respeita uma organização e as qualidades ou atributos associados a ela (Rindova et al., 2005, Carroll, 2011). Carroll e McCombs (2003) oferecem alguns princípios norteadores que ajudam a compreender a influência da cobertura midiática na reputação corporativa, afirmando que quanto maior a cobertura, maior a conscientização do público; atributos enfatizados na cobertura da mídia tornam-se atributos que o público usa para definir uma empresa; e a credibilidade da cobertura noticiosa, positiva ou negativa, reflete-se nas correspondentes percepções do público sobre esses atributos. Embora esses princípios tenham sido desenvolvidos tendo em mente o ambiente corporativo, eles podem ser considerados igualmente válidos para a compreensão do significado da reputação dentro do contexto de place branding (Murphy, 2010; Boisen et al., 2011).

Assim como a imagem e a reputação das organizações, o significado das marcas de lugares pode mudar e evoluir ao longo do tempo, principalmente devido a mudanças no contexto cultural e na linguagem ou nas expectativas da sociedade. Como resultado, place branding como ferramenta de construção de reputação é essencialmente um esforço cumulativo de longo prazo, sem garantia de sucesso (Anholt, 2010b; Roper, 2010). É importante, porém, que tanto a imagem do lugar quanto o que ele representa, componham a base de valores admirados por seus diversos públicos.

\section{Discussão}

A economia das localidades, juntamente com a cultura e as características de seu povo, atua como uma exposição ao cenário mundial (Kavaratzis, Warnaby \& Ashworth, 2014), determinando ritmos de desenvolvimento e prosperidade, assim como a política, sendo parte integrante dessas relações e um importante canal de informação por meio da diplomacia, influencia a composição de sua imagem (Anholt, 2010b). Em termos de desacreditar os esforços de construção de reputação por meio de iniciativas em place branding, medidas políticas equivocadas podem enfraquecer o valor da marca uma vez que geram desencontro em relação 
as características distintivas da localidade que são atraentes para potenciais mercados. Em outras palavras, enquanto o place branding requer consistência para construir confiança no longo prazo, ideologias e interesses políticos tendem a afastar a estabilidade gerando confusão e comportamento imprevisível (Aronczyk, 2009; Volcic \& Andrejevic, 2011). Nesse contexto, o caso do Brasil ilustra o fato de que uma liderança forte e um planejamento eficiente para o desenvolvimento da nação devem prevalecer sobre o interesse político, caso contrário, o crescimento socioeconômico do país, sua imagem e reputação correm o risco de serem comprometidos por múltiplos atores políticos, eleições periódicas, corrupção, ideologias e populismo.

\subsection{Brasil em contexto}

Nos últimos anos, uma estratégia de reposicionamento da marca Brasil alavancou o reconhecimento do país como um polo promissor de investimentos para uma grande variedade de setores. O objetivo geral era agregar novos atributos à imagem do país, como uma economia forte de um país jovem e moderno, renovado, inovador e sustentável, além de fortalecer as características positivas pelas quais o país já era conhecido tais como seu povo amistoso e hospitaleiro, e sua privilegiada e vasta beleza natural. Ao realizar iniciativas de gestão para a marca-país e sediar megaeventos esportivos como ferramentas de promoção internacional Copa do Mundo de Futebol da FIFA em 2014 e Jogos Olímpicos em 2016 no Rio de Janeiro o Brasil buscou se consolidar como uma nação de alta capacidade organizacional, solidez econômica global e interesse pela cooperação internacional se destacando como democracia próspera e economia desenvolvida (Ocke, 2013). No entanto, o Brasil não mostrou o seu melhor, mas sua deficiência em gestão pública e corrupção generalizada que conduziram o país para uma crise política e econômica de escala nunca antes vivenciada. Como resultado, a expresidente Dilma Rousseff enfrentou processo de impeachment sob a acusação de ter financiado ilegalmente déficits orçamentários e foi afastada da presidência da república resultando em um clima de incerteza generalizada. Desta forma, os esforços pretendidos para promoção de imagem positiva foram dominados por problemas evidentes e descontentamento de mercados internos e se tornaram uma desvantagem para os investidores internacionais, afetando negativamente a reputação do país.

Ao longo de 2021, uma série de revelações contundentes em depoimentos oficiais no Congresso nacional acerca da resposta catastrófica do governo à crise de Covid-19, mostrou que o Presidente da República Jair Bolsonaro subestimou a real ameaça do vírus, promoveu 
tratamentos comprovadamente ineficazes, se opôs às medidas de restrição de mobilidade criticando o distanciamento social, promoveu aglomerações sem o uso de máscara e, apenas mais de um ano após o início da pandemia acatou a vacinação para controle da crise sanitária, apesar de seu posicionamento pessoal contrário às vacinas. Além disso, os constantes ataques retóricos à democracia e os insuficientes esforços do governo na gestão ambiental, evocaram pedidos de impeachment. Tais manifestações negacionistas, amplamente cobertas pela mídia internacional (The Economist, 2021; The Guardian, 2021; The New York Times, 2021) caracterizaram o governo brasileiro como uma das piores lideranças globais no enfrentamento da Covid-19 e da crise ambiental. Essa incerteza, instabilidade e turbulência cumulativas que prejudicam a imagem do Brasil nos mercados interno e externo tornaram o país um pária internacional, prejudicando sua percepção geral no espectro global, reduzindo o valor da marca, sua atratividade e desenvolvimento econômico no longo prazo.

\subsection{Agenda de pesquisa e painel consultivo}

Com base no construto da imagem do lugar a partir da identidade competitiva e, em certa medida, da conquista da reputação (Anholt, 2010b; Bell, 2016; Mariutti, 2017, Pedeliento \& Kavaratzis, 2019), esta seção apresenta uma série de tópicos a fim de constituir agenda de pesquisa e painel consultivo para acadêmicos, profissionais de branding e marketing no intuito de despertar a atenção, estimular o debate e sugerir caminhos onde os princípios de place branding possam fornecer uma alternativa para incentivar as lideranças brasileiras a cooperarem e colaborarem de forma mais consistente e eficaz no enfrentamento adequado dos desafios do Século XXI (Harari, 2019). Esse conjunto de proposições leva em consideração a perspectiva de nation branding no contexto brasileiro potencializando dois corolários principais: gestão e meta tendências em place branding. O panorama da gestão e suas implicações consistem em (1) place branding organizacional - formas efetivas de estruturar um corpo formal para coordenar ações e atores reconhecendo a participação dos stakeholders nas etapas de tomada de decisão; (2) programa de marca guarda-chuva - a cooperação entre governantes e lideranças para alcançar objetivos comuns em benefício de diferentes setores da economia que são promovidos e comercializados de forma consistente dentro do escopo de nação em que fazem parte; (3) métricas em place branding - a necessidade de aplicar métodos integradores para monitorar e avaliar os resultados dos esforços investidos nas iniciativas de place branding. As meta tendências são necessárias para o mapear caminhos de estudos futuros e consistem em (4) orientação de marca verde - sustentabilidade como ativo competitivo para 
posicionamento de marca; (5) place branding um contexto de transformação digital - conexão de lugares, pessoas e organizações orientadas por dados por meio de uma rede expandida de tecnologia de informação e comunicação; (6) place branding pós Covid-19 - desafios e oportunidades para reconstrução de economias e positiva percepção de localidades em um cenário pós-pandemia.

\subsubsection{Place branding organizacional}

Um grande desafio para desenvolver modelos e ações de gestão de marcas de lugares é a coordenação de um grande número de players que possam impactar o desempenho e a imagem do lugar. A falta de coordenação e fragmentação das estratégias podem levar à inconsistência nas políticas resultando em prejuízo para a eficácia do place branding a longo prazo (Rainisto, 2003). Assim, uma equipe central deve atuar como ponto focal para acompanhar o processo de gerenciamento de marca, distribuir informações, monitorar a taxa de sucesso e fornecer ferramentas necessárias para um programa bem-sucedido. No âmbito do país, ter o governo federal liderando o processo é importante, pois trata-se de uma entidade abrangente sob a qual vários setores se beneficiarão de iniciativas em place branding, no entanto, a gestão da marca deve estar separada da política (Aronczyk, 2013) e ter participação ativa de regiões produtivas, estados, municípios, além de cultivar parcerias público-privadas, pois ambos os parceiros trazem uma riqueza de informações que ajudam a criar ideias e estratégias criativas para implementação de place branding.

O PBO eficiente deve listar os principais componentes para cada atividade, incluindo formas de operar e implementar planos de ação, matriz de custos operacionais, cronogramas de execução e atribuição de responsabilidades a todos os participantes para evitar ações conflitantes (Kavaratzis \& Ashworth, 2008; Ocke \& Ikeda, 2014). Além disso, movidos por seus próprios interesses, cada um desses atores pode apoiar ou prejudicar as ambições de estabelecer e manter uma determinada marca-lugar (Insch, 2011; Botschen et al., 2017). Para evitar que isso ocorra, examinar as possibilidades de cooperação de forma mais consistente e eficaz entre os atores para alcançar objetivos comuns é essencial para definir um padrão de estilo e tom de mensagens de marca, especialmente em um território tão complexo e amplo como o Brasil. Esse alinhamento pode ser a chave para estabelecer um órgão de coordenação de ações e integração de métodos que ajudem a preparar as localidades para lidar com um futuro incerto, causado por mudanças nas variáveis dos ambientes interno e externo. 
4.2.5 Programa de marca guarda-chuva

A gestão de place branding não deve ser controlada por uma única entidade, mas por um grupo de stakeholders que buscam um plano para tomar decisões em torno de uma identidade com características distintivas para que o lugar possa se destacar dos demais e comunicar claramente seus benefícios e pontos fortes a mercados potenciais, investidores, visitantes e moradores. Uma vez que os lugares são compostos por esses diversos stakeholders com diferentes prioridades e mercados-alvo com características específicas, a composição de uma marca guarda-chuva (Aaker, 1991; Keller, 1993; Kotler \& Gertner, 2011) pode ser essencial para alcançar um terreno comum e focar em pontos fortes do lugar. As imagens de marca de interesse comum em áreas funcionais distintas por meio de uma arquitetura e extensão de marca devem se concentrar em uma estratégia unificadora que evite uma visão compartilhada de lugar. Trata-se então de uma gama de oportunidades para governadores, formuladores de políticas públicas, desenvolvedores econômicos, líderes comunitários, câmaras de exportação, agências de atração de talentos, organizações de marketing de destinos, consultores e demais gestores de marca.

No entanto, a procura por uma mensagem unificadora que atenda simultaneamente diferentes mercados-alvo leva ao risco de a comunicação tornar-se dispersa e abstrata, assemelhando-se a uma marca demasiadamente semelhante a localidades concorrentes, não apelativa a nenhum público ou orientada para um determinado perfil deixando outros mercados desatendidos. Para evitar esse resultado, é essencial potencializar a co-criação entre stakeholders (Rainisto, 2003; Zenker, 2011; Govers, 2020) como forças comunitárias, incluindo sociedade civil, empresários, pesquisadores e especialistas no processo decisório. Nesses termos, uma estratégia coerente de marca guarda-chuva fortalece o senso de lugar ao realizar uma narrativa consistente entre as entidades, pois os stakeholders têm sua própria identidade e cria alinhamento entre a linguagem e as mensagens canalizadas para diferentes públicos. Esforços e investimentos devem ser compartilhados em ações de branding fragmentadas para atender a diferentes mercados-alvo, trabalhando em subdivisões apoiadas por uma identidade de marca-país (Fan, 2010; Kaneva, 2011; Dinnie, 2015). Não apenas as promessas promocionais precisam ser cumpridas para obter credibilidade e demonstrar integridade, mas as marcas das localidades devem ser trabalhadas de forma consistente com as estratégias do país do qual fazem parte. 


\subsubsection{Métricas em place branding}

A gestão de marca vista como forma de governança deve considerar o planejamento de longo prazo, estudos de viabilidade e análise de impactos ambientais e socioeconômicos para a execução de programas de ação eficientes e duradouros. Os efeitos de um programa de place branding podem levar anos para obter resultados e, nesse contexto, as iniciativas devem incluir a definição de métricas baseadas nos objetivos propostos por esses programas como um conjunto de KPIs claros - indicadores-chave de desempenho - a serem articulados e acordados antes do engajamento em iniciativas de place branding (Kavaratzis, 2009; Go \& Govers, 2012). Estudos comparativos entre cidades, regiões ou países concorrentes, indicam quo sucesso dos programas é sempre relativo, portanto, benchmarking de desempenho pode contribuir a determinar o impacto de tais iniciativas. Nesse sentido, a combinação de rankings competitivos mundiais pode fornecer insights valiosos, pois uma posição favorável pode garantir orçamentos maiores para projetos atuais e futuros. Assim, é possível compreender e calcular o retorno do investimento em place branding, com base na relação benefício-custo de atração de mercados bem como no tempo e investimento necessários para um retorno favorável.

Conhecer a metodologia dos rankings é importante, pois cada um vem com estudos diferentes para determinar ou medir o sucesso em place branding e dificilmente apresenta uma construção tangível de valor de marca. A maioria das métricas não é abrangente e limitada a indicadores econômicos, enquanto características intangíveis determinantes do produto do lugar são difíceis de medir e capturar em rankings. Indicadores econômicos e dados quantitativos são relevantes, mas precisam vir acompanhados de indicadores qualitativos de valor de marca (Mariutti \& Giraldi, 2021), porém, cada método tem suas limitações e, portanto, nenhuma abordagem de mensuração de sucesso é perfeita. Métricas focadas em fatores econômicos e quantitativos podem ser complexas em função da dificuldade em determinar a causalidade, uma vez que algumas melhorias na imagem do lugar podem ser devidas a outros fatores e não no esforço de place branding isoladamente. Além disso, quantificar os resultados desejados, como felicidade, experiências positivas, conscientização ou percepção, é extremamente difícil, custoso e demorado, uma vez que essas métricas envolvem o levantamento de uma ampla gama de públicos internos e externos continuamente ao longo do tempo (Anholt, 2020). Eventualmente, a percepção global positiva da imagem de um lugar pode valorizar sua atratividade e desenvolvimento econômico no longo prazo. 


\subsubsection{Marca verde}

Embora o posicionamento e a promoção de lugares com base em suas atrações naturais e credenciais ambientais não sejam novidade, com o crescente reconhecimento e conscientização das questões ambientais, a ênfase nos aspectos de sustentabilidade ambiental tanto no branding corporativo quanto no place branding tornou-se mais frequente. Como enfatizam Morgan, Pritchard e Pride (2011), o contexto global de expectativas ambientais e crescentes preocupações com a degradação ambiental, especialmente as mudanças climáticas, tornam indispensável esta orientação para sobrevivência no mercado global e impulsiona as localidades a constituírem uma participação de destaque na liderança ambiental. Anholt (2010b) destaca que pessoas, empresas e governos se sentem incapazes de admirar ou respeitar países que poluem o planeta, praticam e permitem corrupção, desrespeitam direitos humanos ou violam leis ambientais. Nesse sentido, o green place branding transcende a política e a diplomacia na medida em que os países buscam conquistar os corações e mentes da comunidade internacional (Morgan et al., 2011).

A orientação de marca verde se destaca uma vez que os valores ambientais constituem a essência da marca (Insch, 2011) e o planejamento de curto prazo para impulsionar a atividade econômica não prejudica a sustentabilidade social e ambiental em detrimento da rápida recuperação econômica (Kavaratzis \& Florek, 2021). No entanto, se vagamente definido, o green place branding pode ser propenso a acusações de greenwash (Delmas \& Burbano, 2011; Insch, 2011), ou seja, alegações ambientais feitas para sugerir responsabilidade ambiental que não são apoiadas por evidências. Como Roper (2012) demonstrou, surgem questões onde as promessas de integridade ambiental da marca colidem com as agendas políticas que priorizam o crescimento econômico e o desenvolvimento. Portanto, sem integridade, o green place branding é uma estratégia de alto risco (Roper, 2010) e, em última análise, um posicionamento de marca verde será bem-sucedido no longo prazo apenas se os atributos e benefícios proclamados forem percebidos como ambientalmente corretos (Hartmann, Apoalaza \& Sainz, 2005; First \& Khetriwal, 2008).

Dinnie (2015) observa que as organizações de marketing de destinos turísticos, em particular, tendem a se basear fortemente em atrações naturais, correndo assim o risco de sobrecarregar suas credenciais ambientais. Este fato tem sido particularmente comum em países latino-americanos com tendência ao posicionamento turístico apenas ao invés de construir uma abordagem mais abrangente e incorporar elementos de place branding para equilibrar as estratégias (Kotler et. al, 2006). Os gestores da marca devem se concentrar nas forças naturais do lugar e em seus recursos humanos, em vez de tentar incluir todos seus atributos competitivos. Nesse sentido, a sustentabilidade como posicionamento de place branding pode ser uma oportunidade de mercado global para o Brasil, uma vez que seu ambiente natural e potencial de implantação de matriz 
energética renovável são fortes ativos de sua identidade competitiva. Negar a emergência climática sob a perspectiva de place branding prejudica o país, a região ou a cidade e seu povo.

\subsubsection{Place branding e transformação digital}

Conforme Kotler, Kartajaya e Setiawan (2021), a aplicação de tecnologias que imitam conhecimento humano para criar, comunicar, entregar e aumentar o valor em toda a jornada do cliente por meio de um conjunto de técnicas - inteligência artificial, processamento de linguagem natural, robótica, tecnologia de sensores, realidade aumentada, realidade virtual, internet das coisas e blockchain - irão emular as capacidades das redes de informação e comunicação em expansão, permitindo a conexão de lugares, pessoas e organizações moldando a sociedade 5.0. Nesta realidade orientada por dados, apesar das inovações urbanas desiguais conduzidas digitalmente, especialmente em países em desenvolvimento como o Brasil e seus vizinhos na América Latina, o surgimento de cidades inteligentes é um desenvolvimento lógico e natural de clusters tradicionais e sua expansão para megacidades conectadas globais (GreboszKrawczyk, 2021). Na orientação de place branding no contexto de cidades inteligentes, as ações devem assentar na construção e desenvolvimento de uma identidade competitiva alicerçada em fortes diferenciais e na implementação de iniciativas de longo prazo focadas na inventividade dos cidadãos, na inteligência coletiva e no desenvolvimento urbano baseado no conhecimento, criando um espaço exclusivo e ecossistema de inovação empresarial liderado por tecnologias e mão de obra altamente qualificada (Kolotouchkina \& Seisdedos, 2018).

Por outro lado, o rápido avanço tecnológico abre as portas para um mundo de ferramentas e bases de informações amplamente incompreendidas, capazes tanto de contribuir como prejudicar o desenvolvimento social e econômico (Harari, 2019). Nesse cenário, a digitalização impulsionou o desenvolvimento de fontes crescentes de informação disponíveis nas mídias sociais gerando inverdades e desinformação generalizada. Países, regiões e cidades devem estar atentos na implementação de ferramentas, regulamentação e comunicação honesta para mitigar os impactos da desinformação. Nesse contexto, potencializar a diplomacia digital (Collins \& Bekenova, 2019; Collings, DeWitt \& LeFebvre, 2019; Mazumdar, 2021), apoiar a narrativa digital sobre impressões e experiências de lugares de forma significativa (Hudak, 2019), engajar os meios de comunicação, auxiliam as mensagens e os esforços de proteção da marca, contribuindo na defesa das localidades contra informação enganosa - fake news protegendo não apenas sua reputação, mas a comunidade local e internacional da desinformação (Bloom Consulting, 2021). 


\subsection{6 place branding pós Covid-19}

Governos mundiais enfrentam a difícil tarefa de reconstruir suas economias, na medida que os países tentam emergir com uma reputação intacta após a pandemia de Covid-19. Esse cenário atrai acirrada competição entre as localidades para convencer investidores, talentos e visitantes a confiar em sua administração pública e considerá-los dignos de seu tempo e recursos financeiros. Como impacto imediato, as mensagens criativas são a chave para comunicar os aspectos de saúde e segurança de uma forma que afeta a vontade das pessoas de visitar, morar, trabalhar ou estudar, entre outras prioridades dos públicos de interesse. A política pública e seus esforços para ajudar os cidadãos locais e globais na busca por cuidados de saúde acessíveis e de qualidade está além de uma oferta de valor único e, além disso, uma necessidade básica de lugares que esperam atrair mercados com certo nível de mobilidade e poder de compra. Conforme demonstrado por um painel de especialistas (The Place Brand Observer, 2021), o turismo doméstico aumentará, devido ao esforço conjunto dos governos para impulsionar a recuperação econômica. No entanto, o turismo ambiental e socialmente responsável pode não ser uma prioridade em muitas regiões nos próximos anos, uma vez que contribuir com os negócios deverá ser uma preocupação mais imediata. Eles também reforçam que o trabalho remoto está se tornando cada vez mais atraente e lugares em todo o mundo estão aproveitando esta oportunidade para desenvolver programas de talentos e turismo voltados para atração, retenção e crescimento de talentos locais e internacionais. Indivíduos que têm a oportunidade de se mudar, seja por meios financeiros, liberdade de viagem ou flexibilidade de trabalho remoto, buscarão uma nova qualidade de vida anteriormente inacessível à maioria da comunidade global. Essa mudança na oferta e na demanda em termos de estilo de vida e de trabalho acelerados pela pandemia, traz enormes oportunidades para algumas localidades, especialmente aquelas percebidas como seguras, que demonstraram boa gestão da crise e que permaneceram acessíveis durante a pandemia.

Kavaratzis e Florek (2021) consideram que os eventos ocorridos ao longo da pandemia de Covid-19 enfatizaram a necessidade de compreender o papel do place branding em tempos de crise, um dos temas mais relevantes de discussão em agenda futura, tanto no sentido de garantir protocolos de saúde e no que diz respeito a reativação econômica. Por meio de uma pesquisa de análise de percepção de países (Bloom Consulting, 2021), respostas governamentais rápidas e eficazes a crises têm um impacto significativo para as marcas de lugares. Por outro lado, países como o Brasil, que reagiram de forma lenta e ineficaz são igualmente impactados negativamente. Trata-se de uma linha de atenção a qual países, regiões 
e cidades precisam estar cientes e acompanhar os impactos nas percepções, sendo, portanto, uma oportunidade para os governos recuperarem falhas significativas, sejam locais, regionais ou globais. Nesses termos, as localidades devem prestar atenção especial às políticas que estão sendo desenvolvidas em todo o mundo e aos destinos que implementam programas para atrair talentos, visitantes e investidores por meio de percepções aprimoradas. No sentido da complexidade de um país em tempos tão difíceis, como afirma Anholt (2020), o papel de uma nação no contexto global se destaca pela percepção positiva de sua contribuição de forma substancial para o mundo além de suas próprias fronteiras. Nesse contexto, um país passa a ser um ator de princípios e colaborativo na comunidade internacional, que melhora a vida de muitas pessoas além de seus próprios cidadãos e beneficia o planeta além de sua própria parcela territorial. Eventualmente, os países que se recuperarem com sucesso da crise de Covid-19 serão aqueles que tiverem seu programa de nation branding bem executado e eficaz em termos de protocolos de saúde, diplomacia de vacinas, política, economia, turismo, imigração e atração de talentos, aumentando o valor da marca-lugar, sua atratividade e desenvolvimento econômico no longo prazo.

\section{Conclusões}

Intrínseco ao conceito de place branding reside a necessidade de moldar uma visão estratégica para enfrentar os desafios por meio de um planejamento orientado para o mercado. Os lugares precisam diversificar seus ativos competitivos e desenvolver mecanismos para adaptar a flexibilidade às condições, fomentando e cultivando características empreendedoras para os desafios contemporâneos. Esse pensamento pode sugerir que a gestão de nation branding deve contribuir para a prosperidade, elevando o padrão de vida do país em todos os aspectos, o que incorre em fatores econômicos, políticos e culturais, uma vez que os benefícios das iniciativas são variados e incluem a capacidade de receber mais investimentos diretos devido à sólida imagem geral do país, incluindo elementos sobre segurança, meio ambiente, estabilidade política e econômica, além da oportunidade de usar um selo "made in" em marcas, produtos e serviços para alavancar números de vendas.

As limitações deste artigo residem na natureza complexa do próprio conceito de place branding e nas variadas perspectivas que abordam os atributos formadores de marca de um lugar, sua diversidade de mercados-alvo, stakeholders e a compreensão de que suas raízes devem ser entendidas como uma forma distinta de branding. O place branding é multidisciplinar em essência, envolve diferentes grupos de interesse, é incorporado com 
intangibilidade e complexidade, abrange múltiplas identidades e requer desenvolvimento de longo prazo para alcançar resultados satisfatórios. Além disso, este artigo não fornece à comunidade respostas para evitar armadilhas como o uso indevido do place branding como ferramenta promocional superficial e não aborda a necessidade de atender demandas urgentes de desenvolvimento mais integrado e eficaz do produto básico do lugar beneficiando mercados internos, especialmente em países em desenvolvimento como o Brasil e seus vizinhos na América Latina. Esses aspectos podem reforçar a perspectiva utópica do place branding como mecanismo de integração de stakeholders com interesses particulares e o ceticismo sobre a hipótese de que place branding aumenta a prosperidade de uma determinada região ao criar melhores condições de bem-estar social.

Por fim, a intenção deste trabalho é chamar a atenção necessária para a pesquisa e a práxis em place branding no contexto brasileiro, uma vez que a maioria das contribuições é amplamente oriunda da Europa, América do Norte e Ásia. O objetivo principal é apresentar caminhos onde os princípios de place branding possam fornecer elementos necessários para incentivar as lideranças brasileiras a cooperarem e colaborarem de forma mais consistente e eficaz para enfrentar adequadamente os desafios futuros, uma vez que o planejamento de longo prazo para o desenvolvimento do lugar deve prevalecer sobre o interesse político, caso contrário, o desenvolvimento socioeconômico do país, sua imagem e reputação correm o risco de serem continuamente desacreditados. Espera-se que o mapeamento apresentado na agenda de pesquisa contribua tanto com estudiosos quanto para profissionais e, nesse sentido, são recomendadas novas pesquisas à partir deste roteiro para explorar o assunto no espectro brasileiro não apenas em termos de país, mas também examinando o fenômeno ao longo de suas regiões produtivas, clusters econômicos, estados, cidades e distritos, cada um com sua complexidade e realidade.

\section{Referências}

Aaker, D. (1991). Managing brand equity. New York: Free Press.

Anholt, S. (2006). Anholt City Brand Index - How the World Views Its Cities (2nd ed). Global Market Insight, Bellevue, WA.

Anholt, S. (2007). Competitive identity: The new brand management for nations, cities and regions. Houndsmills, United Kingdom: Palgrave Macmillan.

Anholt, S. (2008). Editorial: Place branding: Is it marketing, or isn't it? Place Branding and Public Diplomacy, 4(1), 1-6. 
Anholt, S. (2010a). Why 'nation branding' doesn't exist, The Economic Times.

Anholt, S. (2010b). Places: Identity, image and reputation. Houndsmills, United Kingdom: Palgrave Macmillan.

Anholt, S. (2020). The Good Country Equation: How we can repair the world in one generation. Oakland, CA: Berrett-Koehler Publishers.

Aronczyk, M. (2009). Branding the nation: Mediating space, value, and identity in the context of global culture. (PhD thesis), New York University, New York, NY.

Aronczyk, M. (2013). Branding the Nation: The Global Business of National Identity. England: Oxford University Press.

Ashworth G. J., \& Kavaratzis, M. (2008). Place marketing: how did we get here and where are we going? Journal of Place Management and Development, 1(2), 150-165.

Bell, C. (2005). Branding New Zealand: The national green-wash. British Review of New Zealand Studies, 15, 13-27.

Bell, F. (2016) Looking beyond place branding: the emergence of place reputation. Journal of Place Management and Development, 9 (3): 247-254.

Bloom Consulting. (2021). Meta trends and implications for nations and place brands. Available at: https://www.bloom-consulting.com/journal/ Access in October $4^{\text {th }}, 2021$.

Boisen, M., Terlouw, K., \& Bouke, V.G. (2011). The selective nature of place branding and the layering of spatial identities. Journal of Place Management and Development, 4(2), 135147.

Boisen, M., Terlouw, K., \& Groote, P., \& Couwenberg, O. (2018) Reframing place promotion, place marketing, and place branding-moving beyond conceptual confusion. Cities, 80: 4-11.

Botschen, G., Promberger, K., \& Bernhart, J. (2017). Brand-driven identity development of places. Journal of Place Management and Development, 10(2), 152-172.

Butler, R. (1998). Tartam mythology: The traditional tourist image of Scotland. In G. Ringer (Ed.), Destinations: Cultural landscape of tourism (121-139). London, UK: Routledge.

Campelo, A., Aitken, R., Gnoth, J., \& Thyme, M. (2009). Place branding: Representing sense of place. Paper presented at the Australia and New Zealand Marketing Academy (ANZAM) Conference, Monash University, Melbourne, Australia

Carroll, C.E., \& McCombs, M. (2003). Agenda-setting effects of business news on the public's images and opinions about major corporations. Corporate Reputation Review, 6(1), 36-46. 
Carroll, C.E. (2011). Corporate reputation and the news media in the United States. In C.E. Carroll (Ed.), Corporate reputation and the news media: Agenda-setting within business news coverage in developed, emerging, and frontier markets (221-240). New York, NY: Routledge.

Collins, N., Bekenova, K. (2019) Digital diplomacy: success at your fingertips. Place Branding and Public Diplomacy 15, 1-11.

Collins, S.D., DeWitt, J.R. \& LeFebvre, R.K. (2019). Hashtag diplomacy: twitter as a tool for engaging in public diplomacy and promoting US foreign policy. Place Branding and Public Diplomacy 15,78-96.

Coyle, F., \& Fairweather, J. (2005). Challenging a place myth: New Zealand's clean green image meets the biotechnology revolution. Area, 37(2), 148-158.

Cheng, A., Kruger, L., \& Daniels, S. (2003). 'Place' as an integrating concept in natural resource politics: Propositions for a social science research agenda. Society \& Natural Resources: An International Journal, 16(2), 87-104.

Delmas, M.A., \& Burbano, V.C. (2011). The drivers of greenwashing. California Management Review, 54(1), 64-87.

Dinnie, K. (2004). Place branding: overview of an emerging literature. Place Branding and Public Diplomacy, 1(1), 106-110.

Dinnie, K. (2008). Nation branding: Concepts, issues, practice. Oxford, United Kingdom: Butterworth-Heinemann.

Dinnie, K. (2015). Nation Branding: Concepts, Issues, Practice. ( $2^{\text {nd }}$ ed). Routledge.

Eisinger, P. (2000). The politics of bread and circuses. Building the city for the visitor class. Urban Affairs Review, 35(3), 316-333.

Fainstein S. (1990). The changing world economy and urban restructuring. (Judd, D., \& Parkinson, M. Eds) Leadership and Urban Regeneration, 31-50. Newbury Park: Sage

Fan, Y. (2010). Branding the nation: Towards a better understanding. Place Branding and Public Diplomacy, 6(2), 97-108.

Fesenmaier, D., \& MacKay, K. (1996). Deconstructing destination image construction. Tourism Review, 51(2), 101-108.

Fetscherin, M. (2010) The determinants and measurement of a country brand: the country brand strength index. International Marketing Review, 27 (4): 466-479

First, I., \& Khetriwal, D.S. (2008). Exploring the relationship between environmental orientation and brand value: Is there fire or only smoke? Business Strategy and the Environment, 19, 90-103.

Florek, M., \& Insch, A. (2008). The trademark protection of country brands: Insights from New Zealand. Journal of Place Management and Development, 1(3), 292-306. 
Florek, M., \& Kavaratzis, M. (2014). From brand equity to place brand equity and from there to the placebrand. Place Branding and Public Diplomacy, 10 (2): 103-107.

Gaio. S., \& Gouveia, L. (2007). O Branding Territorial: Uma Abordagem Mercadológica à Cidade. Revista A Obra Nasce, Edições UFP, 27-36.

Gertner, D. (2011). Unfolding and configuring two decades of research and publications on place marketing and place branding. Place Branding and Public Diplomacy, 7(2): 91-106.

Giraldi, J. M. E., \& Ikeda, A.A. (2009). Uma Aplicação da Abordagem de Personificação no Estudo de Imagem de País. BBR. Brazilian Business Review. 6(1), 137-153.

Gnoth, J. (2002). Leveraging export brands through a tourism destination brand. Journal of Brand Management, 9(4/5), 262-280.

Go, F., \& Govers, R. (2012). International Place Branding Yearbook 2012: Managing Smart Growth and Sustainability. London: Palgrave Macmillan.

Gold, J.R., \& Ward, B. (Eds.). (1994). Place promotion: The use of publicity and marketing to sell towns and regions. Chichester, UK: John Wiley \& Sons Ltd.

Govers, R., \& Go, F. (2009). Place Branding: Virtual and Physical Identities, Glocal, Imagined and Experienced. Palgrave-Macmillan, Basingstoke.

Govers, R., \& Go, F. (2016). Place branding: Glocal, virtual and physical identities, constructed, imagined, and experienced. Springer.

Govers, R., \& Go, F. (2009). Place branding: Glocal, virtual and physical identities, constructed, imagined and experienced. Basingstoke, United Kingdom Palgrave Macmillan.

Govers, R. (2020). Imaginative communities and place branding. Place Branding and Public Diplomacy 16, 1-5.

Grabow, B., Henckel, D., Hollbach, B. (1995). Weiche Standortfaktoren (Soft Location Factors), Kohlhammer/Deutscher Gemeindeverlag, Berlim.

Grebosz-Krawczyk, M. (2021) Place branding (r)evolution: the management of the smart city's brand. Place Branding and Public Diplomacy 17, 93-104.

Gudjonson, H. (2005). Nation Branding. Journal of Place Branding, Vol 1, pp.283-298.

Haider, D., Kotler, P., \& Rein, I. (1994). There's no place like our place! Public Management, 76(2), 15-18.

Hall, T. (1998). Urban Geography, London: Routledge.

Hall, T., \& Hubbard, P. (1998). The entrepreneurial place and the new urban politics. In T. Hall \& P. Hubbard (Eds), The entrepreneurial place: geographies of politics, regime and representation (1-23). Chichester: Wiley. 
Hankinson, G. (2004). The brand images of tourism destinations: A study of the saliency of organic images. Product \& Brand Management, 13(1), 6-14.

Hanna, S., \& Rowley, J. (2008). An analysis of terminology in place branding. Place Branding and Public Diplomacy, 4(1), 61-75.

Harari, Y.N. (2019). 21 lessons for the $21^{\text {st }}$ century. United Kingdom: Vintage Publishing.

Hart, C., \& Stachow, G. (2010). Exploring place image: Formation and measurement. Journal of Place Branding and Public Diplomacy, 6(2), 145-155.

Hartmann, P., Apoalaza Ibáñez, V., \& Forcada Sainz, F.J. (2005). Green branding effects on attitude: Functional versus emotional positioning strategies. Marketing Intelligence \& Planning, 23(1), 9-29.

Herezniak, M., \& Morawska, A. J. (2015) City brand strategy evaluation: in search of effectiveness indicators. Journal of Place Management and Development, 8(3), 187-205.

Herstein, R., Berger, R., \& Jaffe, E.D. (2014) How companies from developing and emerging countries can leverage their brand equity in terms of place branding. Competitiveness Review, 24(4), 293-305.

Hudak, K.C. (2019). Resident stories and digital storytelling for participatory place branding. Place Brand Public Diplomacy 15, 97-108.

Insch, A. (2011). Conceptualisation and anatomy of green destination brands. International Journal of Culture, Tourism and Hospitality, 5(3), 282-290.

Jacobsen, B.P. (2012). Place brand equity: a model for establishing the effectiveness of place brands. Journal of Place Management and Development, 5(3), 253-271.

Judd, D. R., \& Fainstein, S. (Eds.). (1999). The tourist place. New Haven: Yale University Press.

Kaneva, N._(2011). Nation branding: Toward an agenda of critical research. International Journal of Communication, 5, 117-141.

Kavaratzis, M. \& Ashworth, G.J. (2005). Place branding: an effective assertion of identity or a transitory marketing trick? Sociale Geografie, 96(5), 506-14.

Kavaratzis, M., \& Ashworth, G. (2008). Place marketing: how did we get here and where are we going? Journal of Place Management and Development, 1 (2): 150-165.

Kavaratzis, M. (2009). What can we learn from city marketing practice? European Spatial Research and Policy, 16(1), 41-58.

Kavaratzis, M., Warnaby, G., \& Ashworth, G. (2014). Rethinking Place Branding: Comprehensive Brand Development for Cities and Regions. London: Springer. 
Kavaratzis, M., \& Florek, M. (2021) Special Section: The future of place branding. Place Branding and Public Dipomacy 17, 63-64.

Keller, K. (1993). Conceptualizing, measuring and managing customer-based brand equity. Journal of Marketing. 57(1): 1-22.

Kleppe, I. A., Iversen, N. M., \& Stensaker, I. G. (2002) Country images in marketing strategies: Conceptual issues and an empirical Asian illustration. Journal of Brand Management, 10(1), 61-87.

Knight, J.G. (2011). New Zealand's 'clean green' image: Will GM plants damage it? Dunedin, New Zealand: Marketing Department, University of Otago.

Kolotouchkina, O. \& Seisdedos, G. (2018) Place branding strategies in the context of new smart cities: Songdo IBD, Masdar and Skolkovo. Place Branding and Public Diplomacy 14, 115-124.

Kotler, P., \& Gertner, D. (2002). Country as brand, product, and beyond: A place marketing and brand management perspective. Journal of Brand Management, 9(4): 249-261.

Kotler, P., Gertner. D., Rein, I., Haider, D. (2006). Marketing de Lugares. Como Conquistar Crescimento de Longo Prazo na América Latina e Caribe. Prentice Hall Brasil.

Kotler, P., \& Gertner, D. (2011). A place marketing and place branding perspective revisited. In N. Morgan, A. Pritchard \& R. Pride (Eds.), Destination brands: Managing place reputation (3rd ed., pp. 33-54). Oxford, UK: Butterworth-Heinemann.

Kotler, P., Haider, D., \& Rein, I. (1993). Marketing Places: Attracting Investment, Industry and Tourism to Cities, States and Nations. The Free Press, New York, NY.

Kotler, P., Kartjaya, H. \& Setiawan, I. (2021). Marketing 5.0 Technology for Humanity. John Wiley \& Sons, Inc. Hoboken, New Jersey.

Kresl, P. (1995). The determinants of urban competitiveness: a survey. North American Cities and the Global Economy, p. 45-68. Thousand Oaks, CA: Sage.

Lucarelli, A. \& Berg, P.O. (2011) City Branding: A State-of-Art Review of the Research Domain. Journal of Place Management and Development, 4 (1): 9-27.

MacDonald, C. (2011). Expression and Emotion: Cultural Diplomacy and Nation Branding in New Zealand. (Master thesis), Victoria University, Wellington. Link

Mariutti, F. G. (2017). The placement of country reputation towards place management. Journal of Place Management and Development, 10(3): 240-253.

Mariutti, F. G., \& Giraldi, J. M.E (2019). How does a brand reputation-driven construct impact on country brand equity? A cross-national study of Brazil and China. Journal of International Consumer Marketing, 31(5): 408-428.

Mariutti, F. G., \& Giraldi, J. M. E. (2020). Country brand equity: The role of image and reputation. BAR-Brazilian Administration Review, 17 (3): 2-24. 
Mariutti, F. G., \& Giraldi, J. M. E. (2021). Branding cities, regions and countries: a roadmap of place brand equity. RAUSP Management Journal, ahead of print, p.1

Mazumdar, B.T. (2021) Digital diplomacy: Internet-based public diplomacy activities or novel forms of public engagement? Place Branding and Public Diplomacy 17: 105-120.

McGibbon, J. (2006). Teppich-swingers and skibums: Differential experiences of ski tourism in the Tirolean Alps. In K. Meethan, A. Anderson \& S. Miles (Eds.), Tourism consumption and representation: Narratives of place and self (140-157). Wallingford, UK: CAB International.

Moilanen, T., \& Rainisto, S. (2009). How to brand nations, cities and destinations. London, United Kingdom: Palgrave Macmillan.

Morgan, N., Pritchard, A., \& Piggott, R. (2002). New Zealand, 100\% Pure: The creation of a powerful niche destination brand. Journal of Brand Management, 9(4/5), 335-354.

Moufahim, M., Humphreys, M., Mitussis, D., \& Fitchett, J. (2007). Interpreting discourse: A critical discourse analysis of the marketing of an extreme right party. Journal of Marketing Management, 23(5), 537-558.

Murphy, P. (2010). The intractability of reputation: Media coverage as a complex system in the case of Martha Stewart. Journal of Public Relations Research, 22(2), 209-237.

Ocke, M. (2013). Marca e imagem de um país: considerações sobre a Copa do Mundo de 2014 e a promoção do Brasil. Podium: sport, leisure and tourism review. 2(2): 95-120.

Ocke, M. (2018). O Produto ampliado dos lugares: uma perspectiva de marketing. Revista Interdisciplinar de Marketing. 2, 139-155.

Ocke, M., \& Ikeda, A. A. (2014). Marketing de lugar: estado da arte e perspectivas futuras. Revista de Administração da USP, 49(4): 671-683.

Olins, W. (2002). Branding the nation - The historical context. Journal of Brand Management. 9(4/5), 241-269.

Olins, W., \& Hildreth, J. (2011). Nation branding: Yesterday, today, and tomorrow. In N. Morgan, A. Pritchard \& R. Pride (Eds.), Destination brands: Managing place reputation (3rd ed., 55-66). Oxford, UK: Butterworth-Heinemann.

Oliveira, M. O. R.; Stefanan, A. A.; Lobler, M. L. (2018). Brand equity, risk and return in Latin America, Journal of Product \& Brand Management, 27(5),557-572.

O'Shaughnessy, J., \& O'Shaugnessy, N.J. (2000). Treating the nation as a brand: Some neglected issues. Journal of Macromarketing, 20(1), 56-64.

Papadopoulos, N., \& Heslop, L. (2002). Country equity and country branding: Problems and prospects. Journal of Brand Management, 4(5), 294-314. 
Papadoulos, N., Cleaveland, M., \& Bartikowski, M. (2018). Beyond country and brand origin: product/brand places associations and the role of place image in behavior and strategy. Guest Editorial. Journal of Product and Brand Management. 27(7), 733-734.

Papen, U. (2005). Exclusive, ethno and eco: Representations of culture and nature in tourism discourses in Namibia. In A. Jaworski \& A. Pritchard (Eds.) Discourse, communication and tourism. Clevedon, United Kingdom: Channel View Publications.

Passow, T., Fehlmann, R., \& Grahlow, H. (2005). Country reputation - from measurement to management: The case of Liechtenstein. Corporate Reputation Review, 7(4), 309-326.

Pedeliento, G., \& Kavaratzis, M. (2019). Bridging the gap between culture, identity and image: A structurationist conceptualization of place brands and place branding. Journal of Product \& Brand Management, 28 (30): 348-363.

Pennington, R. (2004). Brands, Culture and Semiotics (Revisited) in Creative Strategy Development. (Cardoso, P., \& Gaio, S. Eds). Publicidade e Comunicação Empresarial Perspectivas e Contributos. Porto, Edições Universidade Fernando Pessoa, p. 45-61.

Rainisto, S. (2003). Success factors of place marketing: A study of place marketing practice in northern Europe and the United States. Helsinki University of Technology.

Relph, E. (1976). Place and placelessness. London, UK: Pion.

Relph, E. (2004). Temporality and the rhythms of sustainable landscapes. In T. Mels (Ed.), Reanimating places: A geography of rhythms (111-121). Burlington, VT: Ashgate Publishing.

Rindova, V.P., Williamson, I.O., Petkova, A.P., \& Sever, J.M. (2005). Being good or being known: An empirical examination of the dimensions, antecedents, and consequences of organizational reputation. The Academy of Management Journal, 48(6), 1033-1049.

Roper, J. (2010). CSR as issues management. Paper presented at the 60th Annual International Communication Association Conference, Singapore.

Roper, J. (2012). Environmental risk, sustainability discourses, and public relations. Public Relations Inquiry, 1(1), 1-19.

Scott-Smith, G. (2018). Special issue: the evolution of diplomacy. Place Branding and Public Diplomacy 14, 1-3.

Shields, R. (1991). Places on the margin: alternative geographies of modernity. London, UK: Routledge.

Shimp, T., Sharma, S. (1987). Consumer ethnocentrism: Construction and validation of the CETSCALE. Journal of Marketing Research, 24(8), 280-289.

Shimp, T., Saeed, S., \& Madden, T.J. (1993). Countries and their products: A cognitive structure perspective. Journal of the Academy of Marketing Science, 21(4), 323-330. 
Shostack, G. (1977). Breaking Free from Product Marketing. Journal of Marketing, 41, 73 80

The Economist (2021). Brazil's dire decade. Jair Bolsonaro is not the only reason his country is in a ditch. The political system that helped him win office needs deep reform. Available at: https://www.economist.com/leaders/2021/06/05/jair-bolsonaro-is-not-the-only-reasonhis-country-is-in-a-ditch Access in June $3^{\text {rd }}, 2021$.

The Guardian (2021). Tens of thousands of Brazilians march to demand Bolsonaro's impeachment. Available at: https://www.theguardian.com/world/2021/may/29/tens-ofthousands-of-brazilians-march-to-demand-bolsonaros-impeachment.Access in June $3^{\text {rd }}$, 2021.

The New York Times (2021). 'Complete Insanity': Virus-Stricken Brazil Agrees to Host Soccer Tournament. Available at: https://www.nytimes.com/2021/06/02/world/americas/brazil-copa-america-soccertournament.html. Access in June $3^{\text {rd }}, 2021$.

The Place Brand Observer (2021). Place branding 2021: key priorities and trends to watch. Available at: https://placebrandobserver.com/place-branding-priorities-trends-2021/ Access in October $4^{\text {th }}, 2021$.

Van Ham, P. (2008). Place branding: the state of the art. Annals of the American Academy of Political and Social Science, 616(1), 126-149.

Vargo SL, Lusch RF (2008) Service-dominant logic: continuing the evolution. Journal Academy of Marketing Science, 36 (1):1-10

Volcic, Z., \& Andrejevic, M. (2011). Nation branding in the era of commercial nationalism. International Journal of Communication, 5, 598-618.

Walsh, G., \& Wiedmann, K.P. (2008). Branding Germany: Managing internal and external country reputation. In K. Dinnie (Ed.), Nation branding: Concepts, issues, practice (154160). Oxford, United Kingdom: Butterworth-Heinemann.

Warnaby, G. (2009). Towards a service-dominant place marketing logic. Marketing Theory, 9(4), 403-423.

Warnaby G, Medway D (2013) What about the 'place' in place marketing? Marketing Theory, $13(3): 345-363$

Zenker, S. (2011). How to catch a city? The concept and measurement of place brands. Journal of Place Management and Development, 4(1), 40-52.

Zenker, S., \& Jacobsen, B. (2015). Inter-regional Place Branding: Best Practices, Challenges and Solutions. London: Springer. 